\title{
The Glycoside Oleandrin Reduces Glioma Growth with Direct and Indirect Effects on Tumor Cells
}

\author{
Stefano Garofalo, ${ }^{1,2}$ Alfonso Grimaldi, ${ }^{1,3}$ Giuseppina Chece, ${ }^{1}$ Alessandra Porzia, ${ }^{2,4}$ Stefania Morrone, ${ }^{5}$ \\ [DFabrizio Mainiero, ${ }^{5}$ Giuseppina D’Alessandro, ${ }^{1,2}$ Vincenzo Esposito, ${ }^{2,6}{ }^{\circ}$ Barbara Cortese, ${ }^{7}$ Silvia Di Angelantonio, ${ }^{1,3}$ \\ (ㄷ) Flavia Trettel, ${ }^{8}$ and ${ }^{\circ}$ Cristina Limatola ${ }^{2,8}$ \\ ${ }^{1}$ Department of Physiology and Pharmacology, ${ }^{2}$ Istituto di Ricovero e Cura a Carattere Scientifico, Neuromed, 86077 Pozzilli, Italy, ${ }^{3}$ Center for Life \\ Nanoscience-Istituto Italiano di Tecnologia, ${ }^{4}$ Department of Molecular Medicine, ${ }^{5}$ Department of Experimental Medicine, ${ }^{6}$ Department of Neurology and \\ Psychiatry, ${ }^{7}$ Consiglio Nazionale delle Ricerche-Nanotec, Institute of Nanotechnology, Soft and Living Matter Laboratory, Department of Physics, \\ ${ }^{8}$ Department of Physiology and Pharmacology, Laboratory Affiliated with Istituto Pasteur Italia-Fondazione Cenci Bolognetti, Sapienza University, 00185 \\ Rome, Italy
}

Oleandrin is a glycoside that inhibits the ubiquitous enzyme $\mathrm{Na}^{+} / \mathrm{K}^{+}$-ATPase. In addition to its known effects on cardiac muscle, recent in vitro and in vivo evidence highlighted its potential for anticancer properties. Here, we evaluated for the first time the effect of oleandrin on brain tumors. To this aim, mice were transplanted with human or murine glioma and analyzed for tumor progression upon oleandrin treatment. In both systems, oleandrin impaired glioma development, reduced tumor size, and inhibited cell proliferation. We demonstrated that oleandrin does the following: (1) enhances the brain-derived neurotrophic factor (BDNF) level in the brain; (2) reduces both microglia/macrophage infiltration and CD68 immunoreactivity in the tumor mass; (3) decreases astrogliosis in peritumoral area; and (4) reduces glioma cell infiltration in healthy parenchyma. In BDNF-deficient mice (bdnftm1Jae/J) and in glioma cells silenced for TrkB receptor expression, oleandrin was not effective, indicating a crucial role for BDNF in oleandrin's protective and antitumor functions. In addition, we found that oleandrin increases survival of temozolomide-treated mice. These results encourage the development of oleandrin as possible coadjuvant agent in clinical trials of glioma treatment.

Key words: apoptosis; BDNF; glioma; in vivo; invasion; oleandrin

\section{Significance Statement}

In this work, we paved the road for a new therapeutic approach for the treatment of brain tumors, demonstrating the potential of using the cardioactive glycoside oleandrin as a coadjuvant drug to standard chemotherapeutics such as temozolomide. In murine models of glioma, we demonstrated that oleandrin significantly increased mouse survival and reduced tumor growth both directly on tumor cells and indirectly by promoting an antitumor brain microenvironment with a key protective role played by the neurotrophin brain-derived neurotrophic factor.

\section{Introduction}

Glioma is the most diffuse and aggressive neoplasm of the nervous system, characterized by high invasion and proliferation, diffuse apoptosis and necrosis, astrogliosis, and microglia/

Received July 18, 2016; revised Feb. 27, 2017; accepted Feb. 27, 2017.

Author contributions:S.G., A.P., S.M., F.M., V.E., S.D.A., F.T., and C.L. designed research;S.G., A.G., G.C., A.P., S.M., B.C., and S.D.A. performed research; G.D. contributed unpublished reagents/analytic tools; S.G., A.G., G.C., A.P., S.M., B.C., S.D.A., and C.L. analyzed data; S.G., F.M., B.C., S.D.A., F.T., and C.L. wrote the paper.

This work was supported by the Associazione Italiana per la Ricerca sul Cancro [Grant IG2015-16699 to C.L. and My First AIRC Grant (MFAG) 16803 to B.C.].

The authors declare no competing financial interests.

Correspondence should be addressed to Cristina Limatola, Department of Physiology and Pharmacology, Sapienza University, Piazzale Aldo Moro 5, 00185 Rome, Italy. E-mail: cristina.limatola@uniroma1.it.

DOI:10.1523/JNEUROSCI.2296-16.2017

Copyright $\odot 2017$ the authors $\quad 0270-6474 / 17 / 373926-14 \$ 15.00 / 0$ macrophage $(\mathrm{M} / \mathrm{M} \phi)$ infiltration, and is associated with a poor prognosis. Despite continuous progress in neurosurgery, its infiltrative behavior precludes complete tumor resection and this is certainly the main reason for the poor clinical outcome in patients (Giese et al., 2003; Preusser et al., 2011). Standard therapy consists of surgery, radiotherapy, and chemotherapy with temozolomide (TMZ), a cytotoxic imidazotetrazine leading to the formation of O6-methylguanine, which mismatches with thymine in following DNA replication cycles, thus affecting several cellular functions such as apoptosis (Hirose et al., 2001), autophagy (Kanzawa et al., 2004), mitotic catastrophe, and senescence-like events (Hirose et al., 2001). Despite these treatments, glioma invariably recurs with limited increase of patient survival (Stupp et al., 2009); it appears evident that new therapeutic approaches are urgently needed to treat this disease. 
The cardiac glycoside oleandrin, extracted from Nerium oleander, is a potent inhibitor of the $\mathrm{Na}^{+} / \mathrm{K}^{+}$-ATPase pump (McGrail et al., 1991; Li et al., 2013). It is used for the treatment of different cardiac diseases because blockage of the pump results in the increase of intracellular $\mathrm{Na}^{+}$, with reduced activity of the $\mathrm{Na}^{+} / \mathrm{Ca}^{2+}$ exchanger and the consequent increase of intracellular $\left[\mathrm{Ca}^{2+}\right]$ (McConkey et al., 2000; Poindexter et al., 2007). This produces an increase in cardiac muscle contractility and blood pressure (Rosskopf et al., 1993; Jäger et al., 2001). In the last few years, the antitumoral effects of oleandrin were also demonstrated. It is the principal active constituent of PBI-05204, a botanical drug currently in clinical trials (phase I) for solid tumors. In particular, oleandrin targets specifically the human tumor cells overexpressing the $\mathrm{Na}^{+} / \mathrm{K}^{+}$-ATPase $\alpha 3$ isoform, whereas murine tumor cells express both $\alpha 1$ and $\alpha 3$ isoforms in a 1:1 ratio (Raghavendra et al., 2007; Yang et al., 2009; Lin et al., 2008). The binding affinity of oleandrin is 100-fold higher for the $\alpha 3$ versus the $\alpha 1$ subunit (Blanco, 2005; Rajasekaran et al., 2005). The antitumor activity of oleandrin involves antiproliferative and proapoptotic effects on cancer cells, reduced AKT phosphorylation (Raghavendra et al., 2007), increased caspase-3 activity (Nasu et al., 2002), and inhibition of the FGF-2 and NF- $\kappa$ B pathways (Hong et al., 2014). Recently, the neuroprotective effects of oleandrin have been described in murine models of ischemia and in the oxygen glucose deprivation model in vitro and a possible mediator of neuroprotection in these systems is brain-derived neurotrophic factor (BDNF) (Dunn et al., 2011; Van Kanegan et al., 2014). We have demonstrated recently that BDNF reduced the chemotaxis of glioma cells, inhibiting the small G-protein RhoA through the truncated TrkB.T1 receptor, and that BDNF infusion reduced tumor size in glioma-bearing mice (Garofalo et al., 2015).

Here, we investigated for the first time the effect of oleandrin on the progression and development of glioma in mice and report that oleandrin reduced tumor size both in murine and human glioma models. By means of different primary and established human glioma cell lines, we demonstrated a direct effect both in vitro and in vivo because oleandrin reduced tumor size, increasing apoptosis and/or necrosis in tumor mass, and impaired glioma cell proliferation. In addition, we found that oleandrin can modify the tumor microenvironment by enhancing the BDNF level in brain parenchyma, with effects on glioma progression, and reducing $\mathrm{M} / \mathrm{M} \phi$ and $\mathrm{CD}^{+}{ }^{+}$cell infiltration, astrogliosis, and glioma invasion. Interestingly, reduction of BDNF expression (in $b d n f^{+/-}$mice) or silencing TrkB receptors in transplanted glioma cells abolished the effects of oleandrin on tumor size, supporting the hypothesis of a crucial role of the neurotrophin in modulating the anticancer activity of oleandrin. Moreover, when glioma-bearing mice were cotreated with TMZ and oleandrin, a significant increase of survival time was observed compared with TMZ alone.

\section{Materials and Methods}

Materials. Transwell inserts were from BD Biosciences. Anti-pFAK (catalog \#sc-11765) and anti-F4/80 (M-300, catalog \#sc-25839, RRID: AB_2246477) Abs were from Santa Cruz Biotechnology. Anti-Caspase 3 (catalog \#D175, RRID:AB_2069897), anti-GFAP (catalog \#NB300-141, RRID:AB_10001722), and anti-5-bromo-2-deoxyuridine (BrdU,catalog \#NB500169, RRID:AB_341913) were from Novus Biological. Anti-CD68 (catalog \#MCA1957T, RRID:AB_322219) was from AbD Serotec. AntiNeuN (catalog \#MAB377B, RRID:AB_2298772) was from Merck. Secondary Abs were from DAKO. All cell culture media, fetal bovine serum (FBS), goat serum, penicillin G, streptomycin, glutamine, recombinant human EGF, the Thermo Script RT-PCR System, secondary Abs, and
Hoechst (catalog \#33342, RRID:AB_10626776) were from Invitrogen. The PCR kit was from New England Biolabs. Human Alpha $1 \mathrm{cDNA}$ in pCMV6-XL6 (ATP1A1 Myc-DDK-tagged-NM-00701.6) was from Origene. Oleandrin, phalloidin (P5282), TMZ, BrdU, hematoxylin andeosin, Ab anti-actin (catalog \#A2066, RRID:AB_476693), lentiviral transduction particles for TrkB silencing, and Percoll were from SigmaAldrich. The RNeasy Mini Kit was from Qiagen. The Abs anti-pAKT (Ser473) (catalog \#9271S, RRID:AB_10694411) and anti-AKT (catalog \#9272, RRID:AB_329827) were from Cell Signaling Technology. CXCL12 and BDNF were from Peprotech.

Mice and cell lines. The experiments described in the present work were approved by the Italian Ministry of Health in accordance with the guidelines on the ethical use of animals from the European Community Council Directive of September 22, 2010 (2010/63/EU). We used C57BL/6 (WT) and CB17/Icr-Prkdcscid/IcrIcoCrI (SCID) (RRID:IMSR_RBRC02771) mice from Charles River Laboratories and B6.129S4-Bdnftm1Jae/J $\left(\right.$ bdnf $\left.^{+-}\right)$(RRID:IMSR_JAX:002266) from The Jackson Laboratory. We always used 2-month-old male mice.

The GL261 glioma cell line (RRID:CVCL_Y003; kindly provided by Dr. Serena Pellegatta, Istituto Di Ricovero e Cura a Carattere Scientifico, Besta, Milan) was cultured in DMEM supplemented with $20 \%$ heatinactivated FBS, $100 \mathrm{IU} / \mathrm{ml}$ penicillin $\mathrm{G}, 100 \mu \mathrm{g} / \mathrm{ml}$ streptomycin, 2.5 $\mu \mathrm{g} / \mathrm{ml}$ amphotericin $\mathrm{B}, 2 \mathrm{~mm}$ glutamine, and $1 \mathrm{~mm}$ sodium pyruvate. U87MG (RRID:CVCL_0022), A172 (RRID:CVCL_0131), U251 (ATCC, RRID:CVCL_0021), GL15 (RRID:CVCL_5H95; kindly provided by Dr. Emilia Castigli, Perugia University), MZC (kindly provided by Dr. Antonietta Arcella, Neuromed), primary human glioma cells (obtained from patients at Neuromed), primary murine microglia, and astrocytes (obtained as in Catalano et al., 2013), and primary human astrocytes (Thermo Fisher N7805100) were cultured in DMEM supplemented with $10 \%$ FBS. Both WT and mutated p53 glioblastoma multiforme (GBM) cells were used, whereas all the GBM cell lines used had methylated MGMT (http://p53.free.fr/Database/Cancer_cell_lines/Brain_cancer.html; Cimini et al., 2012; Lee, 2016; Biggs et al., 2011, Pinheiro et al., 2017). Human GBM samples (some provided by Dr. Antonio Santoro, Sapienza University) were from patients who gave their informed consent to the use of tissues for research purposes. Primary human GBM cells were obtained as described previously (Sciaccaluga et al., 2010). Derivation and culture conditions for human fibroblast-derived induced pluripotent stem cells (iPSCs) were as described previously (Lenzi et al., 2015). Human iPSC-derived neurons, obtained as described previously (Hill et al., 2016), were provided by Dr. Alessandro Rosa (Sapienza University of Rome). Normal cerebral tissue derived from the prefrontal cortex of patients who died from heart failure (kindly provided by Dr. Eleonora Aronica, with ethics approval of Amsterdam University).

Intracranial injection of glioma. Male C57BL/6, SCID or $b d n f^{+/-}$mice were anesthetized with chloral hydrate $(400 \mathrm{mg} / \mathrm{kg}$, i.p. $)$ and placed in a stereotaxic head frame. Animals were stereotactically injected with $7.5 \times$ $10^{4}$ GL261, $5 \times 10^{4} \mathrm{U} 87 \mathrm{MG} ; 5 \times 10^{5} \mathrm{U} 251$ and GBM19, and $7.5 \times 10^{4}$ shRNA-TkB GL261: a median incision of $\sim 1 \mathrm{~cm}$ was made, a burr hole was drilled in the skull, and cells were injected $2 \mathrm{~mm}$ lateral (right) and 1 $\mathrm{mm}$ anterior to the bregma in the right striatum. Cell suspensions, in PBS $(4 \mu \mathrm{l})$ were injected with a Hamilton syringe at a rate of $1 \mu \mathrm{l} / \mathrm{min}$ at $3 \mathrm{~mm}$ depth. After $17 \mathrm{~d}$, animals were killed for different analyses.

Histopathological evaluation of tumor volume. Brains of glioma-bearing mice were isolated and fixed in $4 \%$ buffered formaldehyde. Coronal brain sections $(20 \mu \mathrm{m})$ were prepared by standard procedures and stained with hematoxylin and eosin. One section every $100 \mu \mathrm{m}$ was collected and the tumor area was evaluated using Image Tool 3.00.

$\mathrm{Ca}^{2+}$ imaging. Fluorescence images were acquired at room temperature $\left(\mathrm{RT} ; 24-25^{\circ} \mathrm{C}\right)$ using a customized digital imaging microscope. Excitation of fluorophores at various wavelengths was achieved using a 1-nm-bandwidth polychromatic light selector (Till Polychrome II) equipped with a $150 \mathrm{~W}$ xenon lamp (Till Photonics). Fluorescence was visualized using an upright microscope (Axioscope 1; Carl Zeiss) equipped with a $40 \times$ water-immersion objective (Achroplan; Carl Zeiss) and a digital 12 bit CCD camera system (Cool Snap EZ; Photometrics). All peripheral hardware controls, image acquisition, and image processing were achieved using MetaFluor software (Molecular Devices). 
Changes in the intracellular $\mathrm{Ca}^{2+}$ level were monitored using the highaffinity $\mathrm{Ca}^{2+}$-sensitive indicator Fluo4-AM (Invitrogen). Neurons were loaded by incubating coverslips for $45 \mathrm{~min}$ at $37^{\circ} \mathrm{C}$ in $1 \mathrm{ml}$ of HEPESbuffered salt solution (HBSS) containing the following (in $\mathrm{mM}$ ): 120 $\mathrm{NaCl}, 5.4 \mathrm{KCl}, 1.8 \mathrm{CaCl}_{2}, 0.8 \mathrm{MgCl}_{2}, 20 \mathrm{HEPES}-\mathrm{NaOH}$, and 15 glucose, $\mathrm{pH} 7.3$, plus $5 \mathrm{mg} / \mathrm{ml}$ bovine serum albumin (BSA) and $5 \mu \mathrm{M}$ Fluo4-AM. For time-lapse recordings, Fluo4-AM was excited at $480 \mathrm{~nm}$ (emission filter D535/40 nm, dichroic mirror 505DCLP). $\mathrm{Ca}^{2+}$ fluorescence changes are presented as $\Delta F / F_{0}=\left(F-F_{0}\right) / F_{0}$, where $F$ is the current fluorescence intensity and $F_{0}$ is the fluorescence intensity before drug application.

TrkB silencing by shRNA. GL261 cells were infected by TrkB shRNA lentiviral particles. Cells $\left(1.6 \times 10^{4}\right)$ were plated in 96-well plates and infected for $24 \mathrm{~h}$ according to the manufacturer's instructions. Transduced cells were selected with $2 \mu \mathrm{g} / \mathrm{ml}$ puromycin. Knockdown efficiency was evaluated by PCR and invasion experiments. Note that the shRNA used is for all the TrkB isoforms.

Transfection of U87MG cells with ATP1A1 cDNA. U87MG cells were plated and allowed to adhere overnight. ATP1A1 cDNA $(1 \mu \mathrm{g})$ was transfected with Lipofectamine 2000 (Invitrogen). Transfection efficiency was evaluated by PCR. Twenty-four hours after transfection, cells were treated with oleandrin and analyzed for viability as described above.

Survival analysis. After tumor cell injection, mice were monitored daily. The end point was determined by lack of physical activity or death. The mean survival time was calculated using the Kaplan-Meier method and statistical analysis was performed using a log-rank test. For cotreatment with TMZ, $10 \mathrm{~d}$ after tumor injection, mice were treated with oleandrin $(0.03,0.3$, or $3 \mathrm{mg} / \mathrm{kg} /$ daily, i.p.), TMZ ( $50 \mathrm{mg} / \mathrm{kg}$, i.p., every $2 \mathrm{~d}$ for a total of 4 times with a stop of 2 weeks) or both. Daily treatment with oleandrin was chosen considering (Ni et al., 2002) the pharmacokinetic analyses performed in mice, where oleandrin has a half-life of $0.4 \mathrm{~h}$ when given intravenously and of $2.3 \mathrm{~h}$ when given orally. The dosing scheme was chosen starting from these data to be reasonably sure that a constant concentration of drug was maintained along the experiment. Animals used in Kaplan-Meier survival studies received up to four TMZ cycles.

BrdU injection. Seventeen days after injection of GL261 or U87MG cells, BrdU was injected into mice (50 mg/kg, i.p.). Two hours later, mice were killed and brains processed for immunostaining.

Immunostaining. Seventeen days after injection of GL261 and U87MG cells, mice were killed and the brains fixed in $4 \%$ formaldehyde and snap frozen. Cryostat sections $(10 \mu \mathrm{m})$ were washed in PBS, incubated with $3 \%$ goat serum in $0.3 \%$ Triton $\mathrm{X}-100$ for $1 \mathrm{~h}$ at room temperature, and then overnight at $4^{\circ} \mathrm{C}$ with specific antibodies in PBS containing $1 \%$ goat serum and $0.1 \%$ Triton $\mathrm{X}-100$. The sections were stained with the following primary Abs: anti-F4/80 (1:50), anti-CD68 (1:200), anti-CASP3 (1: $50)$, anti-BrdU (1:200), and anti-GFAP (1:1000). After several washes, sections were stained with the fluorophore-conjugated antibody and Hoechst for nuclei visualization and analyzed by fluorescence microscope. For BrdU staining, sections were incubated in $1 \mathrm{~N} \mathrm{HCl}$ for $15 \mathrm{~min}$, then in $2 \mathrm{~N} \mathrm{HCl}$ for $25 \mathrm{~min}$ at $37^{\circ} \mathrm{C}$, and neutralized by incubation in 0.1 $\mathrm{M}$ borate buffer. For F4/80 staining, coronal sections were boiled for 10 min in citrate buffer, $\mathrm{pH} 6.0$, at $95-100^{\circ} \mathrm{C}$.

Image acquisition and data analysis. Images were digitized using a CoolSNAP camera (Photometrics) coupled to an ECLIPSE Ti-S microscope (Nikon) and processed using MetaMorph 7.6.5.0 image analysis software (Molecular Devices). Brain slices were scanned by consecutive fields of vision ( $10 \times$ objective lens) to build a single image per section. The percentage of positive cells was measured as the ratio of the area occupied by fluorescent cells versus the total tumor area (by converting pixels to square millimeters). For comparison between different treatments, at least 12 coronal sections per brain around the point of injection were analyzed.

Isolation of NeuN-positive cells and extraction of total RNA. The brains of GBM-bearing C57BL/6 mice were cut in small pieces and single-cell suspension was achieved by enzymatic digestion in trypsin $(0.25 \mathrm{mg} / \mathrm{ml})$ solution in HBSS. The tissue was further mechanically dissociated using a wide-tipped glass pipette and the suspension applied to a $70 \mu \mathrm{m}$ nylon cell strainer. Cells,obtained after a three-step Percoll gradient (GuezBarber et al., 2012) were stained with anti-NeuN Ab $(1: 1000)$ at $4^{\circ} \mathrm{C}$ for
30 min and isolated using a FACSAria II (BD Biosciences). Cell purity was verified by flow cytometry and PCR analysis. After cell sorting, total RNA was isolated by RNeasy Mini Kit and processed for real-time PCR.

Real-time PCR. Contralateral and ipsilateral brain hemispheres of injected mice or cells were lysed in TRIzol reagent (Invitrogen) for RNA isolation. RT-PCR was performed in a I-Cycler IQ Multicolor RT-PCR Detection System (Bio-Rad) using SsoFast Eva Green Supermix (Bio$\mathrm{Rad}$ ) according to the manufacturer's instructions and the cDNAs were amplified with specific primer pairs: bdnf: 5'-TGAGTCTCCAGGACAG CAAA-3' and 5' -TGTCCGTGGACGTTTACTTCT-3'; mmp9: 5' -TAG CTACCTCGAGGGCTTCC-3' and $5^{\prime}$-GTGGGACACATAGTGGGAG G3'; mmp2: 5' -AGGAATCGGGCCTAAAATTG; 3' and 5'-TGCTTTT CAGTGTTTTGGTGA-3'; gapdh: $5^{\prime}$-TCGCTCCCGTAGACAAAATG G-3' and $5^{\prime}$-TTGAGGTCAATGAAGGGGTC-3'. The PCR protocol consisted of 40 cycles of denaturation at $95^{\circ} \mathrm{C}$ for $30 \mathrm{~s}$ and annealing/ extension at $60^{\circ} \mathrm{C}$ for $30 \mathrm{~s}$. For quantification, the comparative threshold cycle $(\mathrm{Ct})$ method was used. The $\mathrm{Ct}$ values from each gene were normalized to the Ct value of GAPDH in the same RNA samples. Relative quantification was performed using the $2^{-\Delta \Delta \mathrm{Ct}}$ method (Schmittgen and Livak, 2008) and expressed as fold changes in arbitrary values.

Measurement of BDNF by ELISA. The brain of mice bearing gliomas was analyzed for BDNF content using a sandwich ELISA (Promega BDNF $E_{\text {MAX }}$ Immuno Assay System) following the manufacturer's instructions.

Cell viability in vitro. To assess the viability of cells exposed to different concentrations of oleandrin, murine and human tumors and normal cells $\left(13 \times 10^{4} / \mathrm{cm}^{2}\right)$ were treated with oleandrin $(0.3,3$, or $30 \mu \mathrm{M})$ for 3 , 8,20 , and $40 \mathrm{~h}$. Cell viability was determined by MTT assay or by staining dead cells as described previously (Volonte et al., 1994). Results are expressed as percentage of cell survival, taking as $100 \%$ the cells treated with vehicle.

Western blot analyses. Cells were stimulated with oleandrin $(3 \mu \mathrm{M})$ and/or CXCL12 $(50 \mathrm{ng} / \mathrm{ml})$ and EGF $(100 \mathrm{ng} / \mathrm{ml})$ for $1 \mathrm{~min}$. The same amount of proteins ( 20 or $50 \mu \mathrm{g} /$ sample) was loaded onto 7.5 or $12 \%$ SDS polyacrylamide gel and transferred to nitrocellulose paper at $4^{\circ} \mathrm{C}$ for $2 \mathrm{~h}$. Blots were incubated for $1 \mathrm{~h}$ with $5 \%$ nonfat dry milk or $3 \%$ BSA in Tris-buffered saline containing $0.2 \%$ Tween 20 to block nonspecific binding sites and then incubated overnight at $4^{\circ} \mathrm{C}$ with specific primary Abs. After washing, membranes were incubated with HRP-conjugated secondary Abs and immunoreactivity was detected by ECL. Densitometric analysis of immunoreactive bands was performed using Chemi-Doc XRS and Quantity One software (Bio-Rad).

$R T-P C R$. Total RNA was isolated from human and murine glioma cells, GBM tissues from patients, microglia, human or murine astrocytes, human neurons derived from iPS cells, or murine NeuN-positive cells using the RNA miniprep. DNA contamination was removed according to the manufacturer's protocol. $500 \mathrm{ng}$ of RNA was reverse transcribed using the Thermo Script RT-PCR System protocol and the cDNAs were amplified by PCR with specific primers: for mouse $\alpha 1,5^{\prime}$-ATCTGA GCCCAAACACCTGCTAGT-3' and ' ${ }^{\prime}$-AAGCGTCCTTCAGCTCTTC ATCCA- $3^{\prime}$; mouse $\alpha 3,5^{\prime}$-AGCCGCCAAGATGGGGGACAAAA- $3^{\prime}$ and 5'-TGTGTCAGACCCTGCACGCAGTC-3'; human $\alpha 1,5^{\prime}$-CTGGCT GGAGGCTGTCATCTTCTTCAT-3' and $5^{\prime}$-GTTGGGGCTCCGATG TGTTGGGGT- ${ }^{\prime}$; human $\alpha 3,5^{\prime}$-CTGGCTGGAGGCTGTCATCTTCTT CAT-3' and 5'-ATCGGTTGTCGTTGGGGTCCTCGGT-3'; mouse actin, $5^{\prime}$-GTCACCCACACTGTGCCCAT- $3^{\prime}$ and $5^{\prime}$-ACAGAGTACTT GCGCTCAGGA-3'; human actin, 5'-TAAGGAGAAGCTGTGCAT CG-3' and $5^{\prime}$-GGAGCAATGATCTTGATCTTC- ${ }^{\prime}$; $\beta$ TubIII, $5^{\prime}$-CGCAC GACATCTAGGACTGA-3' and 5'-TGAGGCCTCCTCTCACAAGT-3'; GFAP, 5'-GGCCGGGGCGCTCAA-3' and 5'-GCCGACTCCCGCGC AT-3'; CX3CR1, 5' -TCACGTTCGGTCTGGTGGG-3' and 5'-GGTTCC TAGTGGAGCTAGGG-3'; CX3CL1, 5' -CTTCCTTTCTCCCCGAGG TA- ${ }^{\prime}$ and $5^{\prime}$-CCAGGCTGGCTATGGTCCAACTG-3'; human TrkBFL, $5^{\prime}$-CTTTGGTAATGCTGTTTCTG- ${ }^{\prime}$ and $5^{\prime}$-CGCGGCGATCTG CTGGGCTAT-3'; human TrkB-T1, 5' -GGGAGGGATGAGAAACAGA TTC- $3^{\prime}$ and $5^{\prime}$-CGGGATAAGCCAACAGCAGTC-3'. The PCR was as follows: DNA was denatured for $2 \mathrm{~min}$ at $94^{\circ} \mathrm{C}$ and sequences were amplified for 35 cycles for $\alpha 3$ and $\alpha 194^{\circ} \mathrm{C}$ for $45 \mathrm{~s} ; 60^{\circ} \mathrm{C}$ for $55 \mathrm{~s} ; 72^{\circ} \mathrm{C}$ for 90 min; for CX3CR1 and CX3CL1 $94^{\circ} \mathrm{C}$ for $30 \mathrm{~s} ; 60^{\circ} \mathrm{C}$ for $30 \mathrm{~s} ; 72^{\circ} \mathrm{C}$ for 2 
a

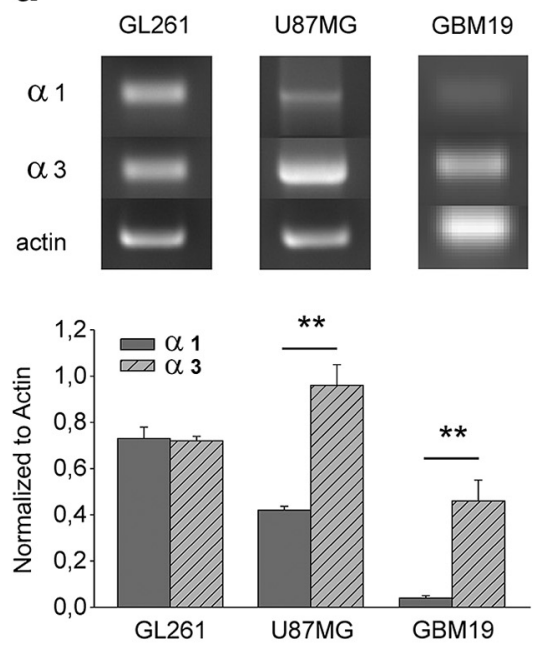

C

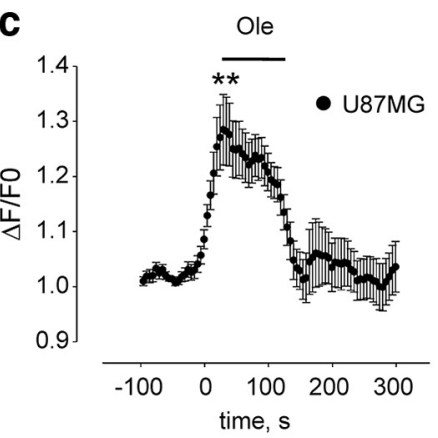

b

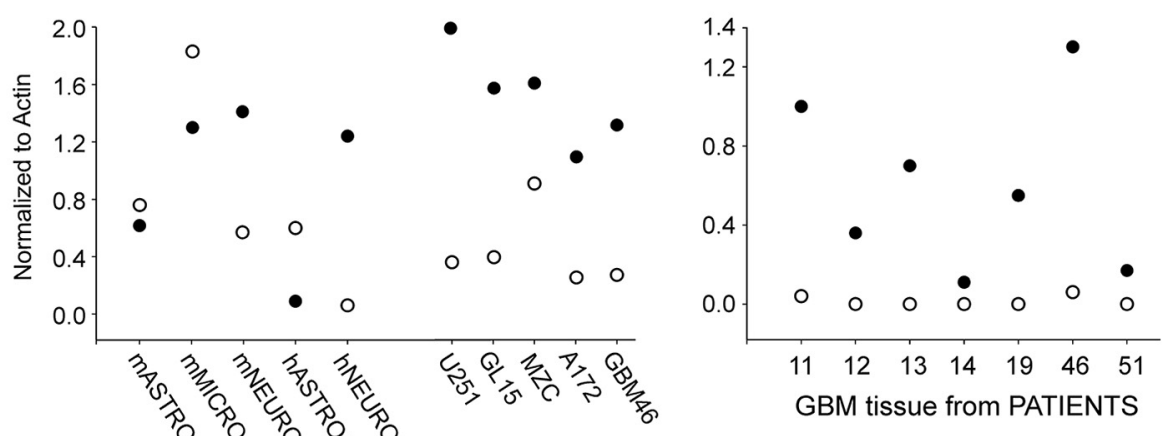

U87MG

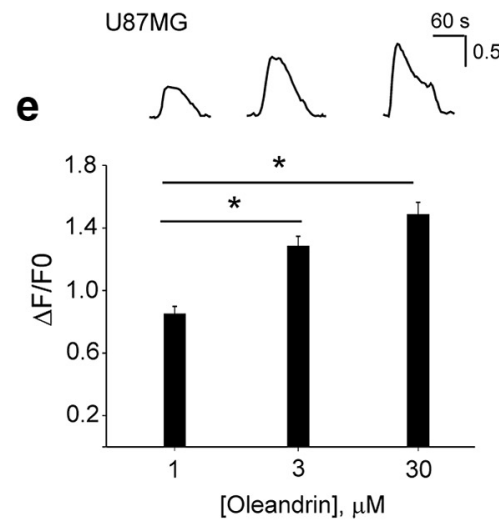

Figure 1. Oleandrin induces $\mathrm{Ca}^{2+}$ transients in human glioma cells. $\boldsymbol{a}, \boldsymbol{b}, \mathrm{RT}-\mathrm{PCR}$ analyses of $\alpha 3$ and $\alpha 1 \mathrm{Na}^{+}-\mathrm{K}^{+}$-ATPase subunit expression in tumor cells, normal cells, and human tissues from patients ( $n=3,{ }^{* *} p<0.01$ one-way ANOVA followed by Holm-Sidak post hoc test). Representative experiments for some glioma cell lines are shown on top. $c$, Effect of oleandrin (1 $\mu \mathrm{m}, 2$ $\mathrm{min}$ ) on $\mathrm{Ca}^{2+}$ transients in U87MG cells expressed as $\Delta F / F 0\left(n=44,{ }^{* *} p<0.01\right)$. $\boldsymbol{d}$, Proportion of U87MG (black bars) and GL261 cells (white bars) displaying $\left[\mathrm{Ca}^{2+}\right]_{\mathrm{i}}$ transients in response to oleandrin $\left(1,3\right.$, and $30 \mu \mathrm{m} ;{ }^{*} p<0.05, \chi^{2}$ test).e, Average of fluorescence responses elicited by 1,3 , and $30 \mu \mathrm{m}$ oleandrin in U87MG cells $\left({ }^{*} p<0.05\right)$. Top, Fluorescence traces from a representative U87MG cell showing the effect of different concentrations of oleandrin on intracellular calcium.

min; for GFAP, actin, $\beta$ TubIII, TrkB-FL, TrkB-T1 $94^{\circ} \mathrm{C} 30 \mathrm{~s} ; 57^{\circ} \mathrm{C} 2 \mathrm{~min}$; $72^{\circ} \mathrm{C} 40 \mathrm{~s}$, followed by the last extension step at $72^{\circ} \mathrm{C}$ for $10 \mathrm{~min}$. A MJ Mini Thermal Cycler (Bio-Rad) was used for all reactions. Products were analyzed on $2 \%$ agarose gels stained by ethidium bromide.

Boyden chamber chemotaxis assays. Semiconfluent cells were trypsinized, preincubated in chemotaxis medium (DMEM without glutamine, 100 $\mathrm{IU} / \mathrm{ml}$ penicillin $\mathrm{G}, 100 \mu \mathrm{g} / \mathrm{ml}$ streptomycin, $0.1 \% \mathrm{BSA}$, and $25 \mathrm{~mm}$ HEPES, pH 7.4) supplemented with AraC $5 \mu \mathrm{m}$ for $15 \mathrm{~min}$ and plated $\left(4 \times 10^{4}\right.$ cells $)$ on poly-L-lysine-coated Transwells ( $8 \mu \mathrm{m}$ pore size filters) in this same medium. The lower chamber contained oleandrin $(0.3,3$, or $30 \mu \mathrm{M})$, EGF $(100 \mathrm{ng} / \mathrm{ml})$, CXCL12 $(50 \mathrm{ng} / \mathrm{ml})$, or vehicle. After $4 \mathrm{~h}$ (U87MG, U251, MZC, GL15, A172, GBM19, and GBM46) or $18 \mathrm{~h}$ (GL261), cells were fixed with trichloroacetic acid. Cells adhering to the upper side of the filter were scraped off and cells on the lower side were stained with a solution containing $50 \%$ isopropanol, $1 \%$ formic acid, and $0.5 \%(\mathrm{w} / \mathrm{v})$ brilliant blue R 250. For each membrane, the stained cells were counted in at least 20 fields with a $40 \times$ objective. Experiments were done in six repeats and performed four times.

Apoptosis assay. Cells $\left(3.5 \times 10^{4}\right)$ were seeded into 12 -well plates (in triplicate) and, after $24 \mathrm{~h}$, treated with oleandrin $(3 \mu \mathrm{M})$ for $10 \mathrm{~h}$. To detect apoptosis, cells were harvested, washed (with buffer containing 10 mM HEPES, $140 \mathrm{~mm} \mathrm{NaCl}$, and $2.5 \mathrm{~mm} \mathrm{CaCl}_{2}$ ), and resuspended in FITC-conjugated Annexin V (Bender MedSystems). After 15 min of incubation at RT, propidium iodide (PI) was added, and the percentage of Annexin V-FITC and Annexin V-FITC/PI-positive cells was determined.

Statistical data analysis. Data are shown as the mean \pm SEM. Statistical significance was assessed by Student's $t$ test or one-way ANOVA for parametrical data, as indicated; Holm-Sidak, test was used as a post hoc test; Kruskal-Wallis for nonparametrical data, followed by Dunn's or Tukey's post hoc tests. For multiple comparisons, multiplicity-adjusted $p$-values are indicated in the respective figures $\left({ }^{*} p<0.05,{ }^{* *} p<0.01\right)$. For statistical analysis of calcium responses in different glioma cell types at different drug concentrations, statistical difference of proportions was obtained with $\chi^{2}$ or $z$ test. For the Kaplan-Meier analysis of survival, the log-rank test was used. All statistical analyses were done using Sigma Plot 11.0 software.

\section{Results}

\section{Oleandrin differentially affects intracellular $\mathrm{Ca}^{2+}$ in human} and murine glioma cells

Before investigating the effect of oleandrin on glioma growth, we analyzed the expression of the $\mathrm{Na}^{+} / \mathrm{K}^{+}$-ATPase subunits $\alpha$ land $\alpha 3$, known molecular targets of this drug, in different human cell lines of GBM, in cells from GBM patients, and in murine glioma cells. We also analyzed the $\mathrm{Na}^{+} / \mathrm{K}^{+}$-ATPase subunit expression in human normal astrocytes and neurons derived from iPSCs and in murine astrocytes, microglia, and neurons. Data shown in Figure 1, $a$ and $b$, demonstrated that all GBM and glioma cell lines and primary cells from patients express both the $\alpha 1$ and $\alpha 3$ subunits at different ratios; that is, higher for human cells (1:2.5 for U87MG and for 1:11.5 for GBM19) with respect to murine GL261 $\left(1: 1, n=3,{ }^{* *} p<0.01\right)$. We also confirmed that neuronal 
a

\section{GL261}

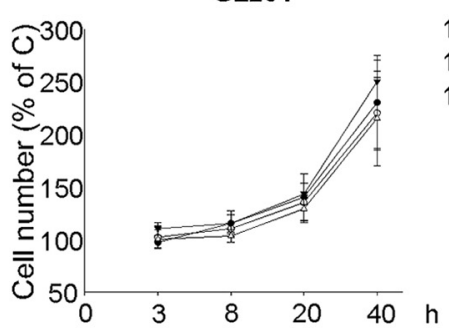

GL15

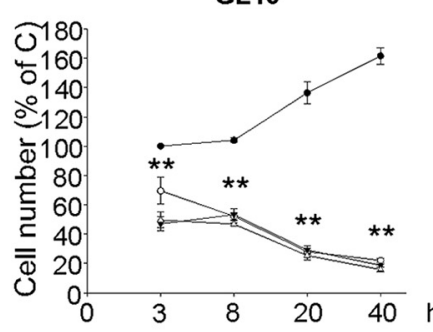

b

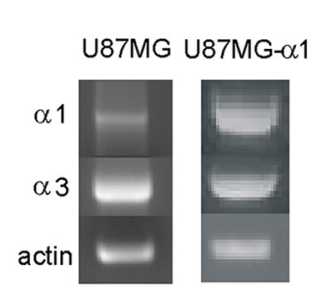

e
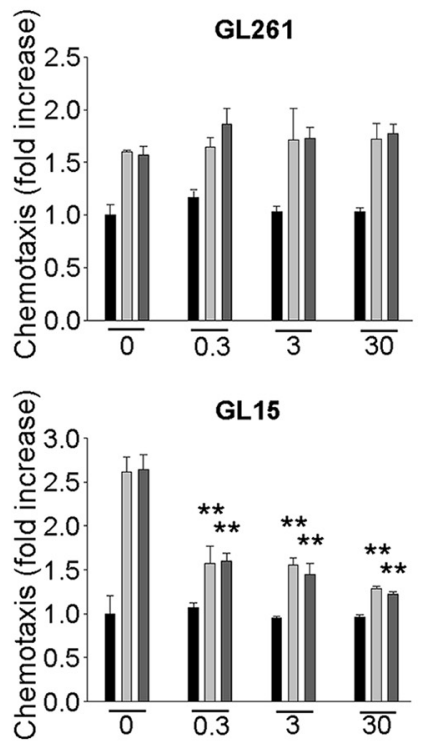

U87MG

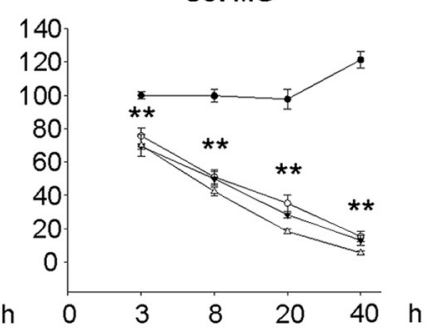

A172

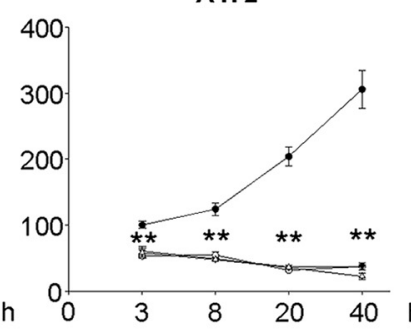

C

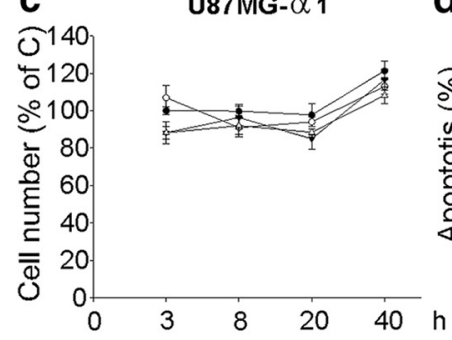

U251

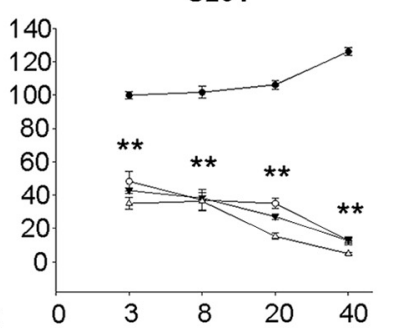

GBM19

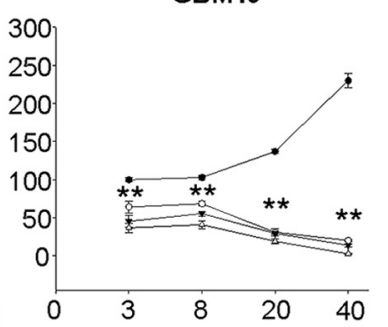

- - Ole $0.3 \mu \mathrm{M}$

$\rightarrow$ Ole $3 \mu \mathrm{M}$

$\triangle-$ Ole $30 \mu \mathrm{M}$

MZC

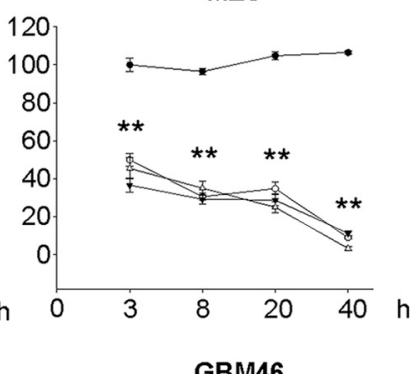

GBM46

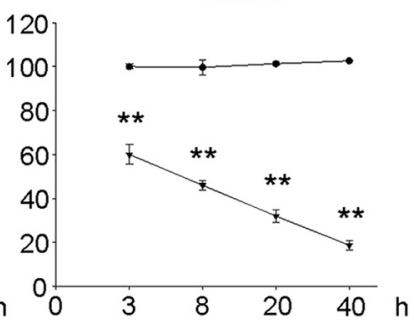

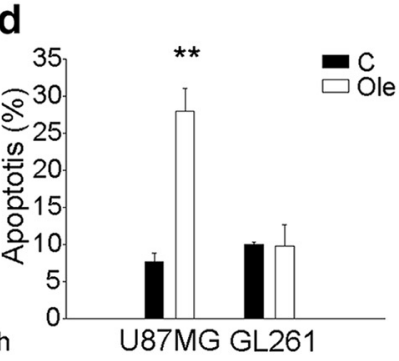
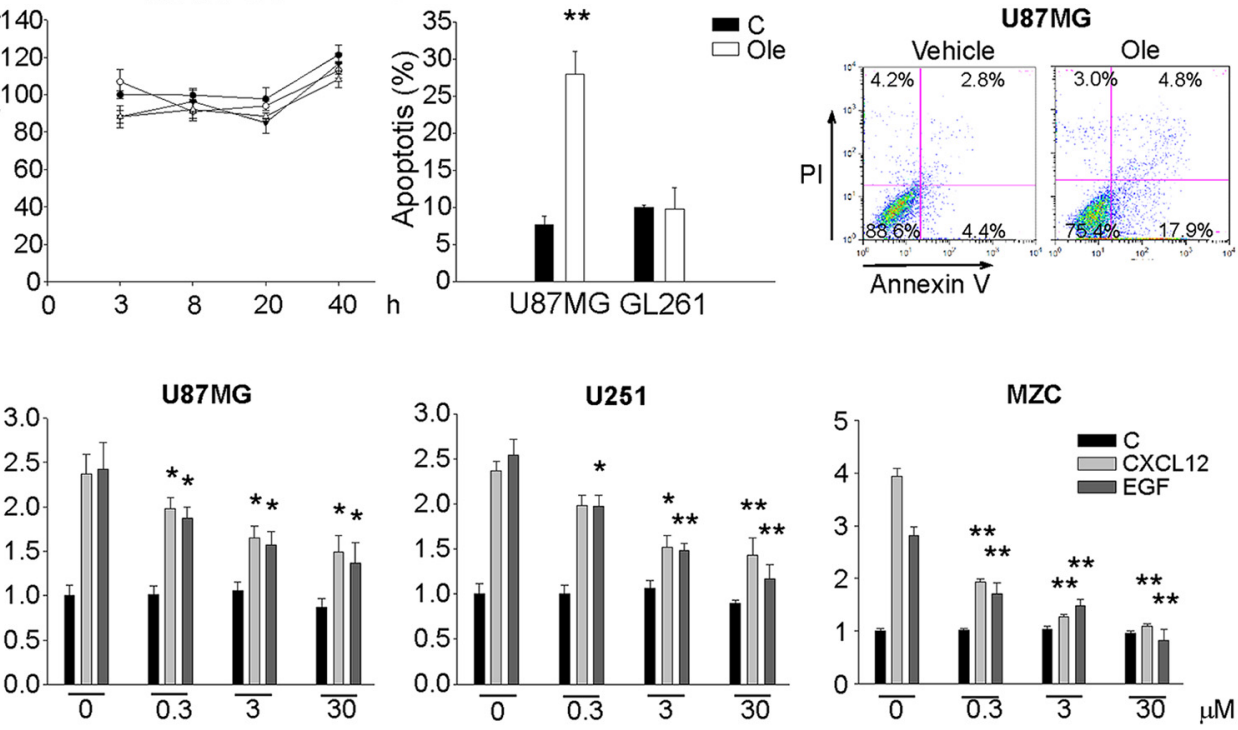

MZC
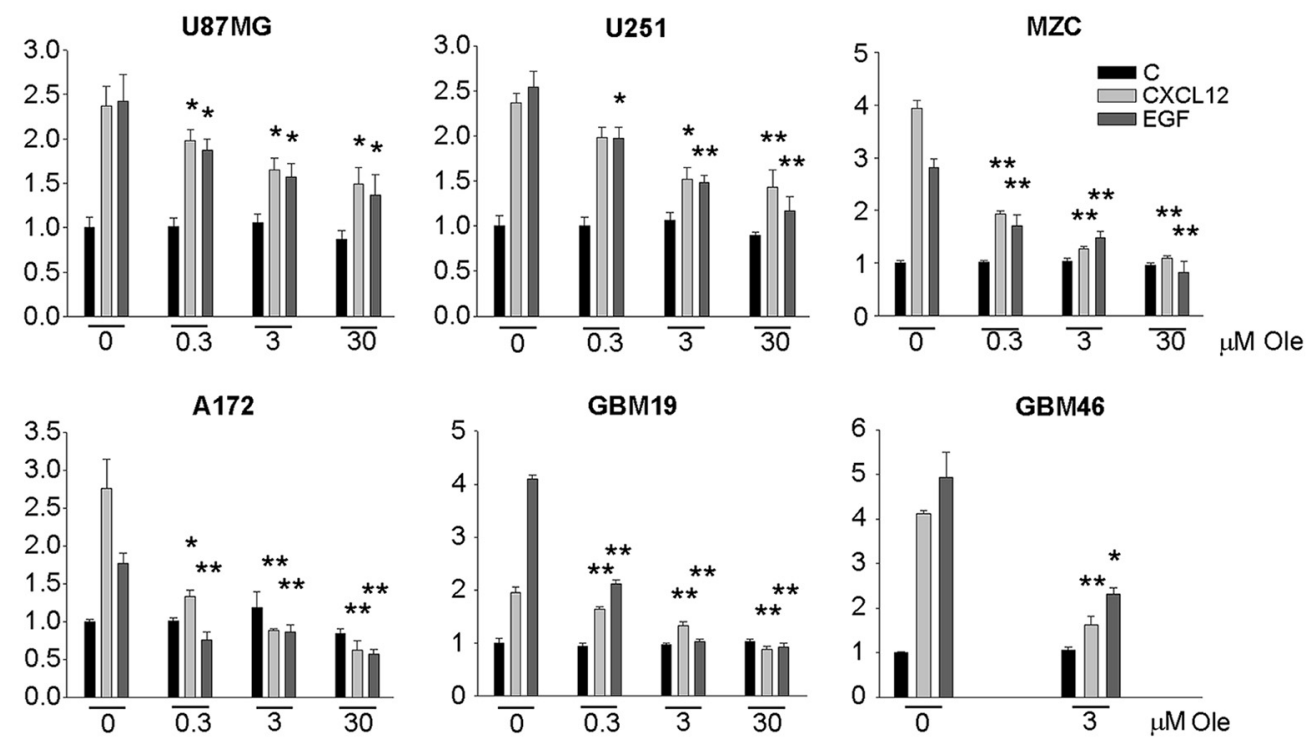

Figure 2. Effects of oleandrin on human and murine glioma cells on viability and migration. $\boldsymbol{a}$, Growth curves of human and murine glioma cells treated with oleandrin for the indicated time points. The results are expressed as percentage of untreated cells at time $0\left(n=4,{ }^{* *} p<0.01\right.$, one-way ANOVA followed by Dunn's post hoc test). $\boldsymbol{b}$, Representative RT-PCR analysis of $\alpha 3$ and $\alpha 1$ $\mathrm{Na}^{+}-\mathrm{K}^{+}$-ATPase subunit expression in U87MG cells transfected with $\alpha 1$ cDNA. $c$, Growth curves of U87MG cells transfected with $\alpha 1$ cDNA treated with oleandrin for the indicated time points $(n=$ 4, one-way ANOVA followed by Holm-Sidak post hoc test). $\boldsymbol{d}$, Induction of apoptosis in glioma cells upon oleandrin treatment ( $3 \mu \mathrm{m}$ for $10 \mathrm{~h}$ ) evaluated by flow cytometry. Data show the mean value of Annexin V-positive plus Annexin V/PI-positive cells expressed as percentage of total cells $\left(n=6,{ }^{* *} p<0.01\right.$, one-way ANOVA followed by Holm-Sidak post hoc test). A representative plot is shown on the right for U87MG. $e$, Human and murine glioma cell chemotaxis toward control medium (C), CXCL12 (50 ng/ml), or EGF (100 ng/ml) in the presence or absence of oleandrin at the indicated doses. Results are expressed as the fold increase in comparison with control $\left(n=4-5,{ }^{* *} p<0.01,{ }^{*} p<0.05\right.$, one-way ANOVA followed by Dunn's post hoc test). 
a
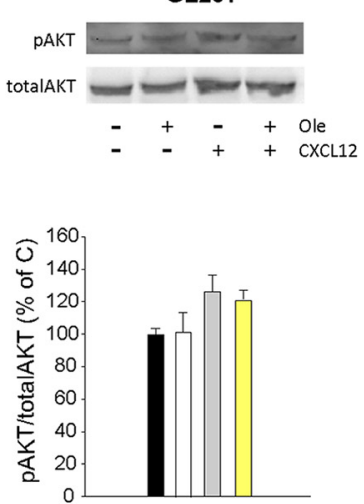

U87MG
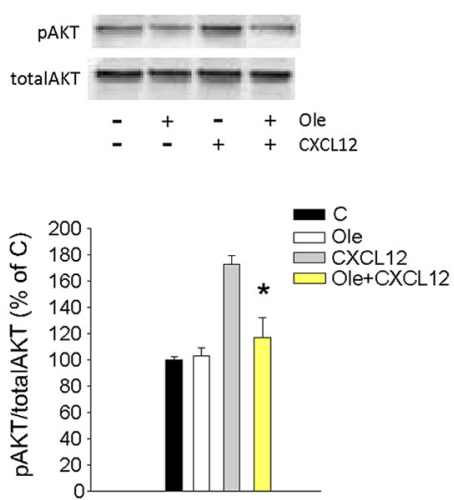

b
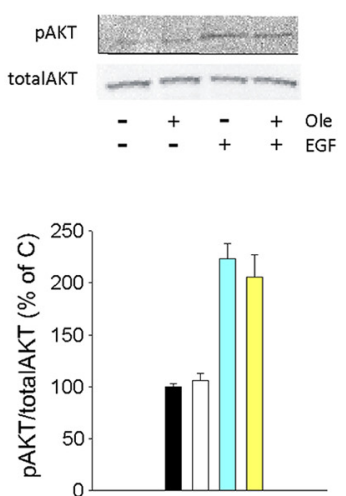
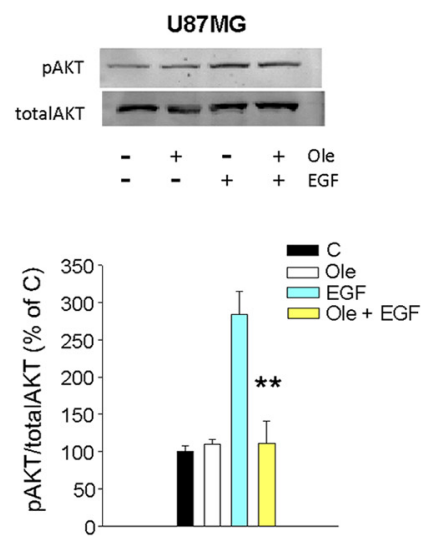

C

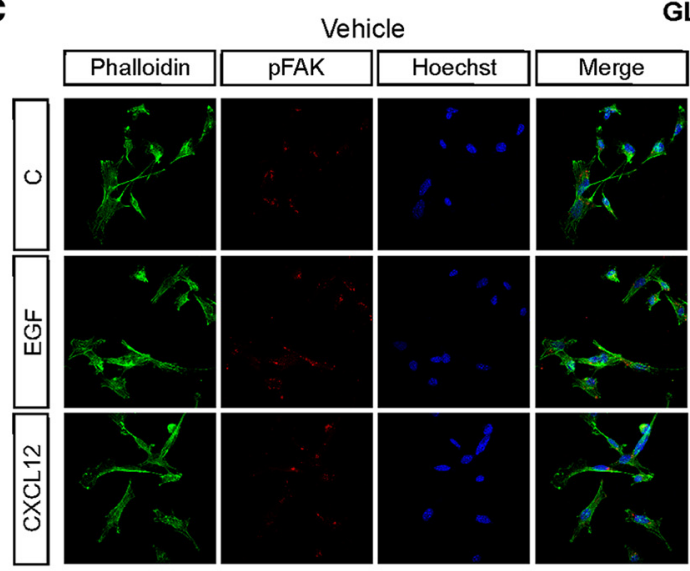

GL261

Oleandrin
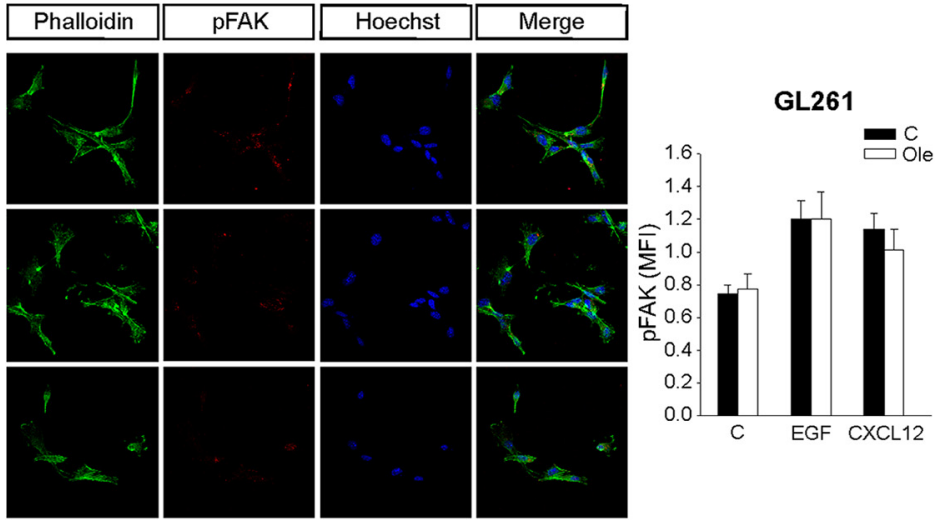

U87MG
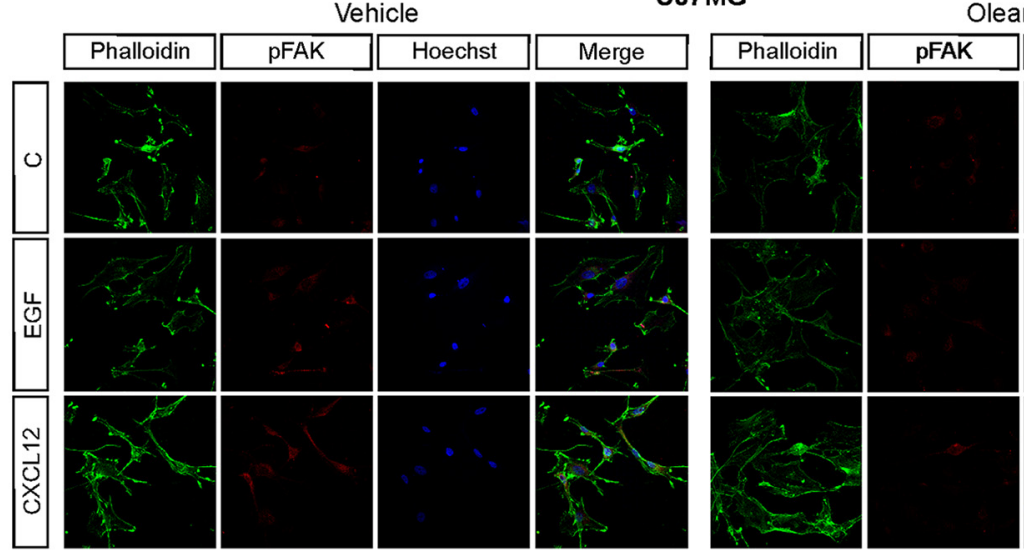

leandrin

d

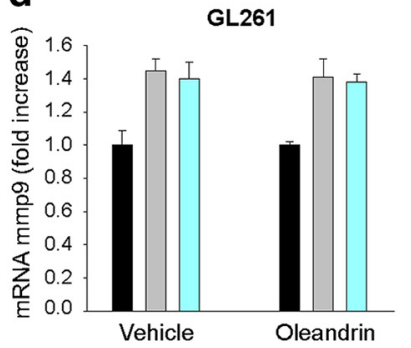

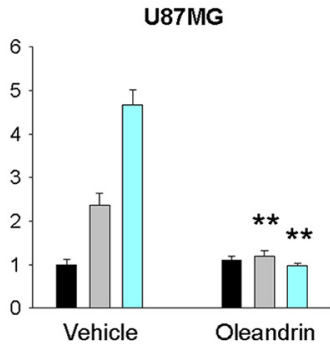

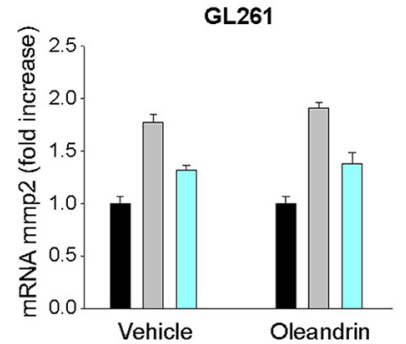

Figure 3. Oleandrin modulates the signaling pathways activated by the chemotactic agents CXCL12 and EGF. $\boldsymbol{a}, \boldsymbol{b}$, Analysis of pAKT in GL261 and U87MG glioma cells upon CXCL12 (50 ng/ml), EGF $(100 \mathrm{ng} / \mathrm{ml})$, and oleandrin $(3 \mu \mathrm{m})$ stimulation $(1 \mathrm{~min})$. Representative experiments are shown on top of each graph. Data were normalized to total AKT and are expressed as percentage of untreated control cells $(C)\left(n=4 ;{ }^{* *} p<0.01,{ }^{*} p<0.05\right.$, one-way ANOVA followed by Holm-Sidak post hoc test). $c$, GL261 and U87MG treated with CXCL12 or EGF in the absence or presence of oleandrin $(3 \mu \mathrm{M})$, stained with phalloidin (green), pFAK (red), and Hoechst (blue) and analyzed for pFAK mean fluorescence intensity (MFI). Representative images are shown on the left ( $n=4$; ${ }^{*} p<0.05$ by one-way ANOVA, followed by Holm-Sidak post hoc test). Note that oleandrin also modified the actin cytoskeleton. $\boldsymbol{d}$, Expression of $m m p 9$ and $m m p 2$ mRNA in GL261 and U87MG treated with CXCL12 or EGF in the absence or presence of oleandrin $(3 \mu \mathrm{M})$, as above. Results of RT-PCR analysis are shown as the fold increase versus control $\left(n=3-5 ;{ }^{* *} p<0.01\right.$, one-way ANOVA on ranks). 
cells express high levels of $\alpha 3$, whereas normal glia (astrocytes and microglia) have higher levels of the $\alpha 1$ subunit (Fig. 1b).

To understand whether such different expression resulted in different functional effects of oleandrin in cells of distinct origins considering the higher affinity for $\alpha 3$ subunit (Blanco, 2005), we measured intracellular $\mathrm{Ca}^{2+}$ transients upon drug treatment. It is known that blockade of the $\mathrm{Na}^{+} / \mathrm{K}^{+}$ATPase affects $\mathrm{Ca}^{2+}$ homeostasis, leading to increase of intracellular of $\mathrm{Ca}^{2+}$ concentrations $\left[\mathrm{Ca}^{2+}\right]_{\mathrm{i}}$ (McConkey et al., 2000). We performed intracellular $\mathrm{Ca}^{2+}$ measurements loading cells with the Fluo4-AM dye. Data obtained indicate that oleandrin $(1 \mu \mathrm{M})$ induces a transient increase of $\left[\mathrm{Ca}^{2+}\right]_{\mathrm{i}}$ in human (U87MG) cells (Fig. 1c). The number of responsive U87MG cells (Fig. 1d) and the level of $\left[\mathrm{Ca}^{2+}\right]_{\mathrm{i}}$ (Fig. 1e) increased with oleandrin dose $(n=44 / 78,98 / 118$, and $115 / 123$ cells at 1,3 , and $30 \mu \mathrm{M}$, respectively; ${ }^{\star} p<0.05$ among $1 \mu \mathrm{M}$ and the other doses). In contrast, murine GL261 cells showed a remarkably different profile of $\mathrm{Ca}^{2+}$ response, with a small proportion of responsive cells only at $30 \mu \mathrm{M}$ oleandrin (23/134 cells; Fig. 1d).

Altogether, these results demonstrate that human glioma cells display higher expression ratio of the $\alpha 3 / \alpha 1$ subunits than murine cells and, consistently, only human (U87MG) cells responded to oleandrin in terms of intracellular $\mathrm{Ca}^{2+}$ transients.

\section{Oleandrin induces apoptosis and reduces migration of human glioma cells in vitro}

To investigate the effects of oleandrin in glioma, cell viability and migration were examined. Data shown in Figure $2 a$ show that oleandrin reduced viability in all human GBM cells in a time-dependent way even at the lowest dose $\left(n=4,{ }^{* *} p<\right.$ 0.01 ), whereas no effect on viability was observed in GL261 cells (Fig. 2a). To verify the hypothesis that the different effects on human and murine cells were due to the different expression ratio of the $\mathrm{Na}^{+} / \mathrm{K}^{+}$ ATPase $\alpha 1$ : $\alpha 3$ subunits, we overexpressed $\alpha 1$ in U87MG cells. Data shown in Figure 2, $b$ and $c$, demonstrate that such manipulation, switching the $\alpha 1: \alpha 3$ ratio to $1: 1.1$, renders U87MG cell growth insensitive to oleandrin even at a higher dose. We then tested the apoptosis of glioma cells exposed to oleandrin $(3 \mu \mathrm{M}$ for $10 \mathrm{~h}$ ) by flow cytometry. Oleandrin treatment resulted in a significant increase of apoptotic frequency in U87MG cells $(n=6$, ${ }^{* *} p<0.01$ ), with no variation in GL261 cells (Fig. $2 d$ ). To evaluate the specific effect of oleandrin on tumor cells, we investi- a

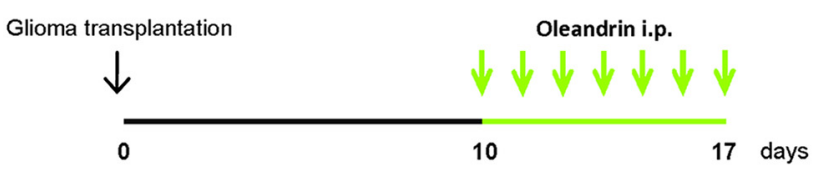

b
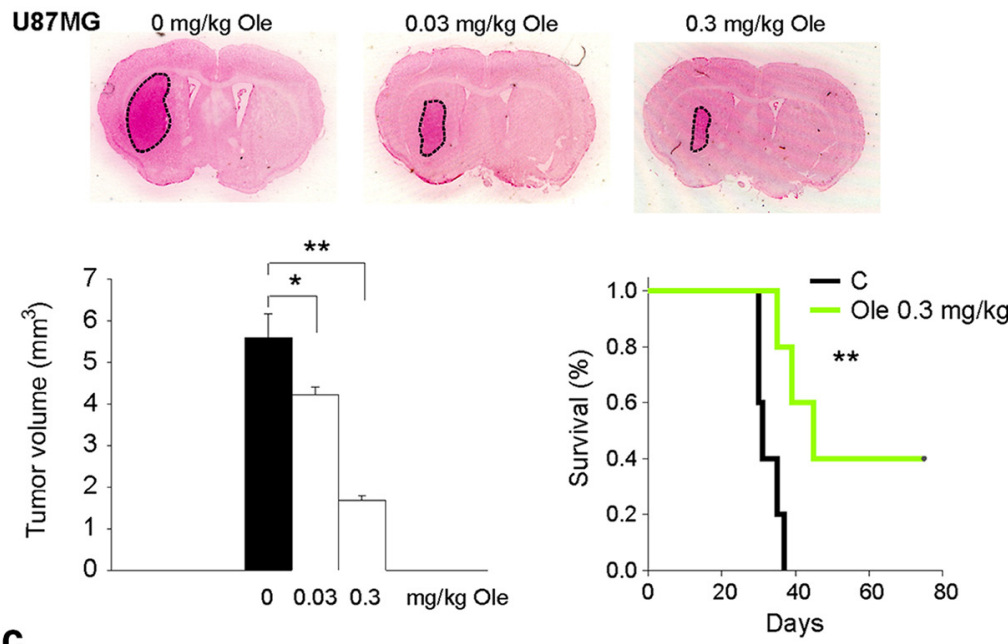

C
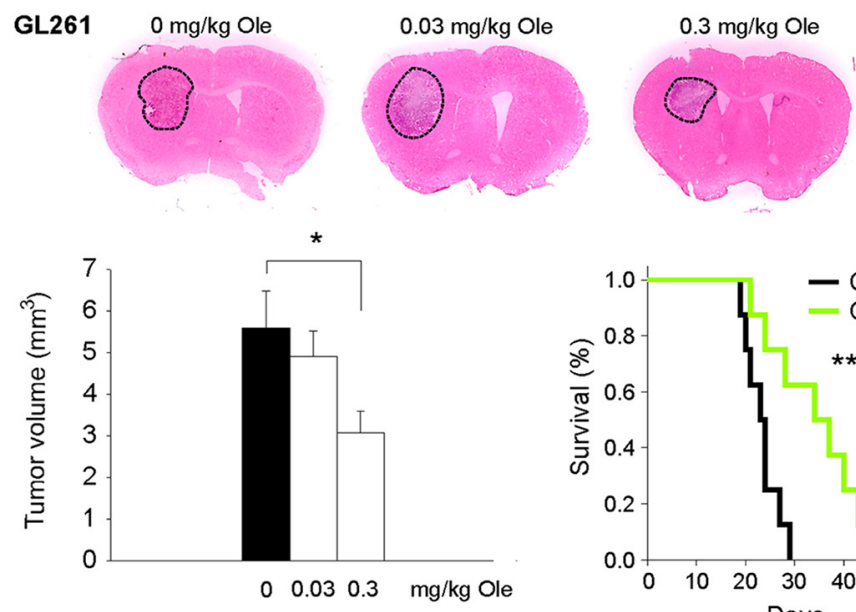

d U251
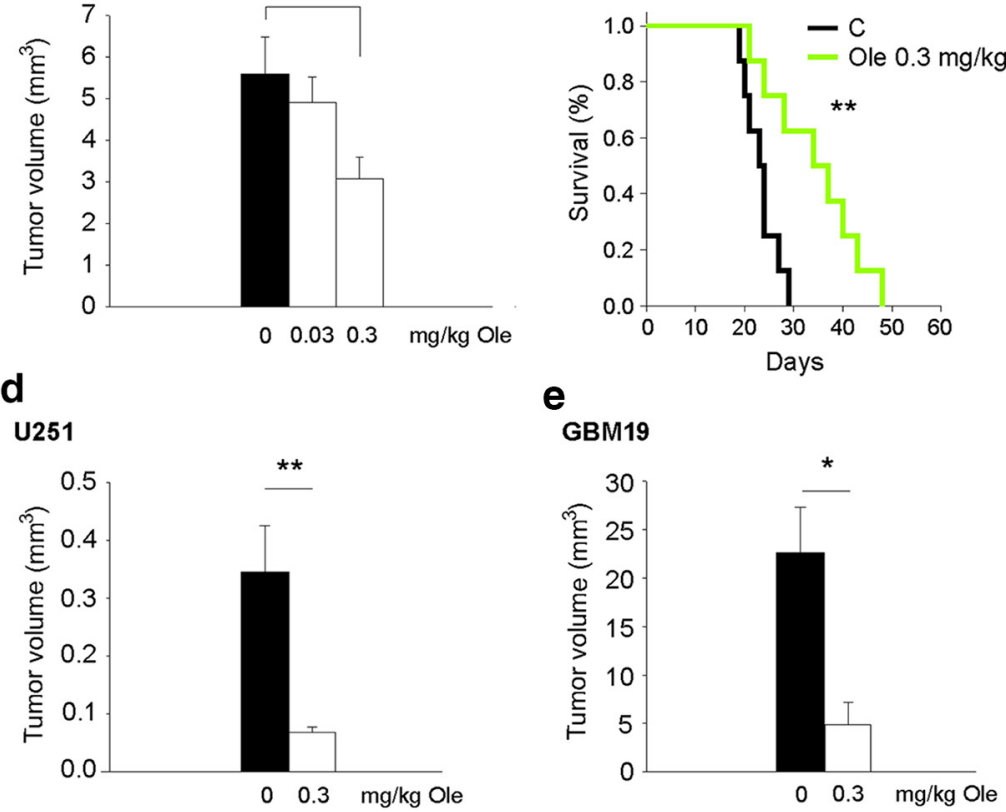

e

GBM19

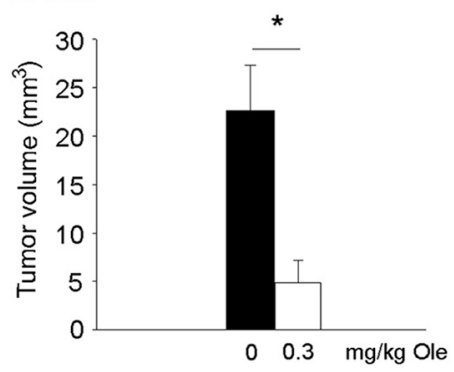

Figure 4. Oleandrin reduces tumor size and increases mouse survival. $\boldsymbol{a}$, Experimental scheme. $\boldsymbol{b}$ - $\boldsymbol{e}$, Mean tumor volumes (left) and Kaplan-Meier survival curves (right) in mice bearing U87MG (b) and GL261 glioma cells (c) and mean tumor volumes in mice bearing U251 (d) and GBM19 (e) glioma cells. All mice were treated with oleandrin, as indicated ( $n=5-11 ;{ }^{*} p<0.05$, ${ }^{* *} p<$ 0.01 , one-way ANOVA followed by Dunn's post hoc test $\left(\boldsymbol{b}, \boldsymbol{c}\right.$, left); ${ }^{* *} p<0.01$ long-rank test $(\boldsymbol{b}, \boldsymbol{c}$, right). Representative coronal brain sections are shown above for U87MG and GL261 at $17 \mathrm{~d}$.

gated the viability of normal human and murine cerebral cells. The effect of oleandrin was tested at doses from 0.3 to $30 \mu \mathrm{M}$ on normal human astrocytes and human iPSC-derived neurons, as well as on primary cultures of murine astrocytes, neurons, or 

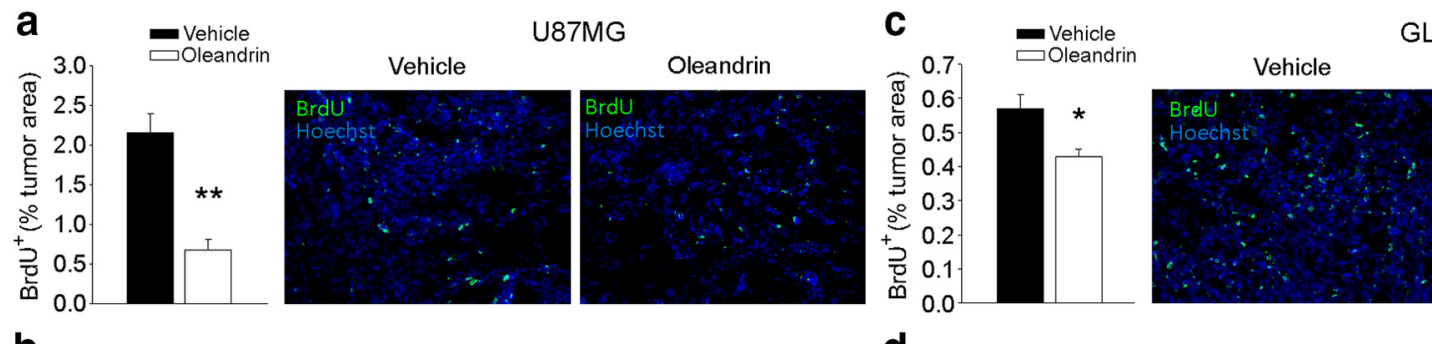

GL261

b

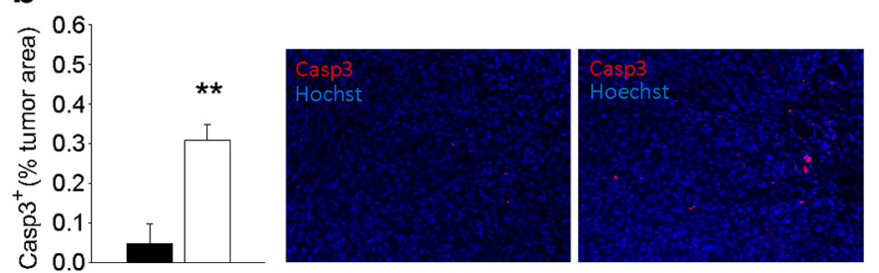

d
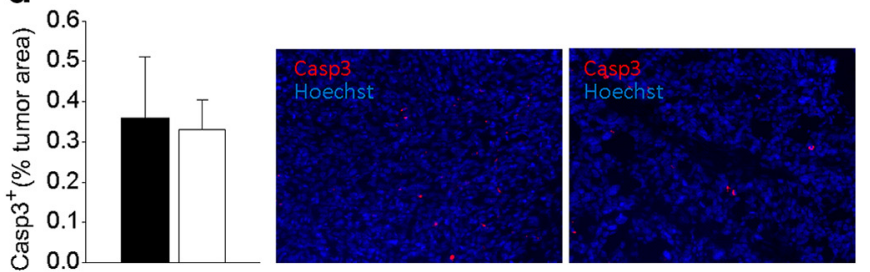

Figure 5. Effects of oleandrin on tumor cell proliferation and apoptosis in vivo. Data show the BrdU ${ }^{+}$cells in brain tumors (expressed as the mean area \pm s.e.m percentage of the tumor) at $17 \mathrm{~d}$

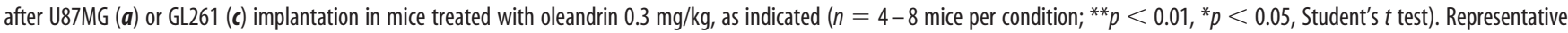
immunofluorescence images of proliferating BrdU ${ }^{+}$cells (green) under the two experimental conditions are shown on the right. Shown is the mean ( \pm SEM) area of Casp3 ${ }^{+}$cells in brain tumors of mice implanted with U87MG (b) or GL261 (d) cells ( $n=4$ mice per condition; ${ }^{* *} p<0.01$, Student's $t$ test). Representative immunofluorescence images of Casp3 ${ }^{+}$cells (red) are shown on the right.

microglia. The viability of these cells was not affected by oleandrin (data not shown); only for microglia did we observe a reduction of cell viability using $30 \mu \mathrm{M}$ oleandrin (at $40 \mathrm{~h}, 70.7 \pm 4.1 \%$ vs control; $n=3$; ${ }^{\star} p<0.05$, one-way ANOVA followed by Holm-Sidak post hoc test).

It is known that cell migration is an important aspect of tumor cell infiltration in brain parenchyma (Miao et al., 2015). The $\mathrm{Na}^{+} / \mathrm{K}^{+}$pump is involved in modulating the activity of ion channels involved in cell migration, like BK (Tajima et al., 2011), and it is also reported to modulate cell migration independently of its pump activity (Barwe et al., 2005; Balasubramaniam et al., 2015). We evaluated the effect of oleandrin on tumor cell migration. Functional assays demonstrated that the migration of human GBM cells toward EGF and CXCL12 was reduced by oleandrin in a dose-dependent way $\left(n=4-5,{ }^{\star} p<0.05,{ }^{\star *} p<\right.$ 0.01 ), whereas GL261 migration was not affected (Fig. 2e). Interestingly, oleandrin also reduced CXCL12- and EGF-induced AKT and FAK phosphorylation in U87MG but not in GL261 cells $\left(n=4-5,{ }^{*} p<0.05,{ }^{* *} p<0.01\right)$, as demonstrated by Western blot and immunofluorescence analyses (Fig. $3 a-c$ ), consistent with the specific functional effects on these cells. These results confirm a direct effect of oleandrin on human tumor cells. Consistent with these results, oleandrin treatment also reduced the chemoattractant-induced increase of metalloproteinases (MMPs) 2 and 9 , thus confirming a wide spectrum effect on tumor cell migration (Fig. $3 d, n=4,{ }^{\star *} p<0.01$ ).

\section{Oleandrin affects tumor growth in mice}

We investigated the effect of oleandrin on glioma growth in vivo. To this aim, SCID or C57BL/6 mice were transplanted, respectively, with human U87MG $\left(5 \times 10^{4}\right)$, U251, GBM19 $\left(5 \times 10^{5}\right)$, or murine (syngeneic) GL261 $\left(7.5 \times 10^{4}\right)$ cells into the right striatum and, after $10 \mathrm{~d}$, treated daily with intraperitoneal oleandrin for an additional $7 \mathrm{~d}$ (Fig. $4 a$ ). Figure 4, $b$ and $c$ (left), show that oleandrin significantly reduced tumor sizes in human and murine glioma cell models in vivo in a dose-dependent way. High concentrations of oleandrin $(3 \mathrm{mg} / \mathrm{kg})$ were fatal in both models, as expected from the known lethal dose for rodents. Doses of oleandrin below the lethal dose $(0.3 \mathrm{mg} / \mathrm{kg})$ significantly in- creased the survival time from $32.6 \pm 1.4 \mathrm{~d}$ to $53.8 \pm 9.6 \mathrm{~d}$ in mice injected with U87MG cells $\left(n=5-11 ;{ }^{* *} p<0.01\right.$, log-rank test) and from $23.37 \pm 1.2 \mathrm{~d}$ to $34.38 \pm 3.3 \mathrm{~d}\left(n=5-11 ;{ }^{* *} p<0.01\right.$, log rank test; Fig. $4 b$, right) in mice injected with GL261 cells (Fig. $4 c$, right). Reductions of tumor volumes were also obtained when different human GBM cells were injected (Fig. 4d,e; U251, control: $0.34 \pm 00.8 \mathrm{~mm}^{3}$, oleandrin: $0.07 \pm 0.01 \mathrm{~mm}^{3}$, ${ }^{* *} p<0.01$ $n=5$ and GBM19, control: $22.6 \pm 4.7 \mathrm{~mm}^{3}$, oleandrin: $4.9 \pm 2.3$ $\mathrm{mm}^{3},{ }^{\star} p<0.05 n=5$ ).

\section{Oleandrin reduces glioma cell proliferation and induces death of glioma cells in vivo}

To investigate the mechanisms by which oleandrin can reduce glioma size in vivo, we analyzed the extent of tumor cell proliferation and death in the brain of glioma-bearing mice. Results reported in Figure 5, $a$ and $b$, demonstrate that oleandrin significantly reduced the extent of BrdU-positive cells (evaluated as described in the Materials and Methods) and increased the percentage of cleaved caspase 3-positive cells in U87MG tumor mass $\left({ }^{*} p<0.01,{ }^{*} p<0.05 ; n=4-8\right.$ mice). Differently, in mice bearing GL261 tumors, oleandrin treatment caused a reduction of BrdU-positive cells, with no variations in the cleaved caspase 3 level (Fig. $5 c, d$ ). These results suggest that the effect of oleandrin on tumor size could be mediated through induction of apoptosis and reduction of tumor cell proliferation in human glioma, whereas in murine cells, the reduction of tumor growth is not dependent on the activation of apoptotic pathways.

\section{Oleandrin reduces glia reactivity and tumor invasiveness}

We analyzed the effect of oleandrin treatment on brain parenchyma of both mouse models, looking at $\mathrm{M} / \mathrm{M} \phi$ infiltration (evaluated as $\mathrm{F} 4 / 80^{+}$cells) and activation of phagocytic activity $\left(\mathrm{CD}^{+}{ }^{+}\right.$cells $)$within the tumor and astrocyte activation at the tumor border (glial fibrillary acidic protein, $\mathrm{GFAP}^{+}$cells). Data shown in Figure 6, $a-c$, demonstrated a significant reduction of $\mathrm{F} 4 / 80^{+}$cell infiltration in the tumor mass, as well as a reduction of $\mathrm{CD} 8^{+}$and double-positive F4/80/CD68 cells, within the tumor $\left({ }^{* *} p<0.01,{ }^{*} p<0.05 ; n=4\right.$ mice). Moreover, astrogliosis, a common feature observed in the peritumoral area, was sig- 
U87MG

GL261
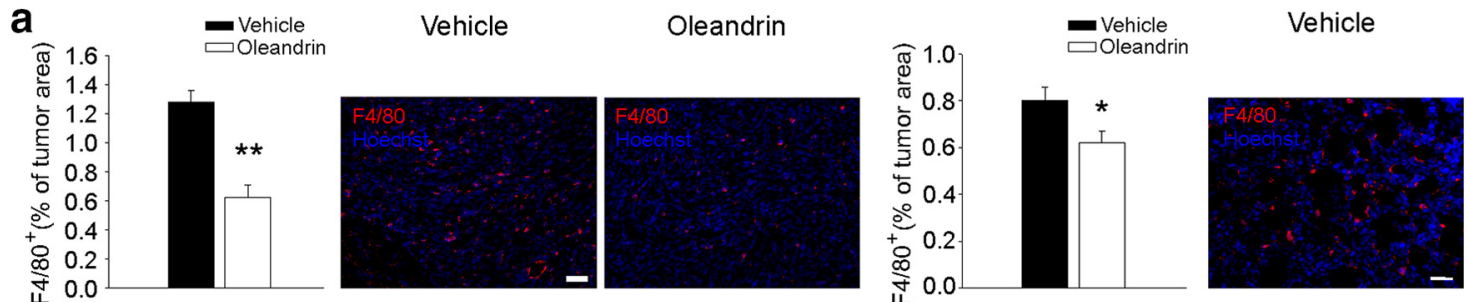

Oleandrin

b
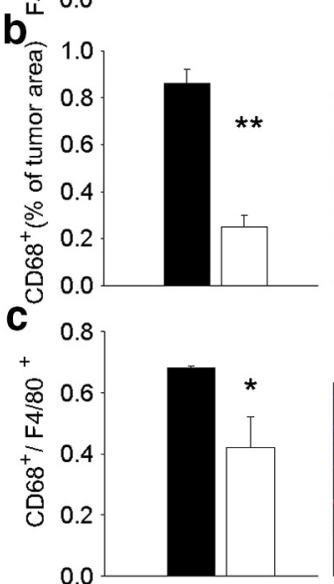

d

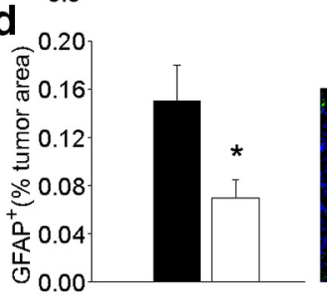

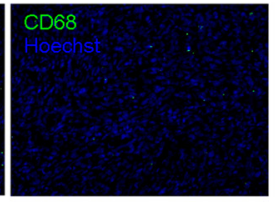
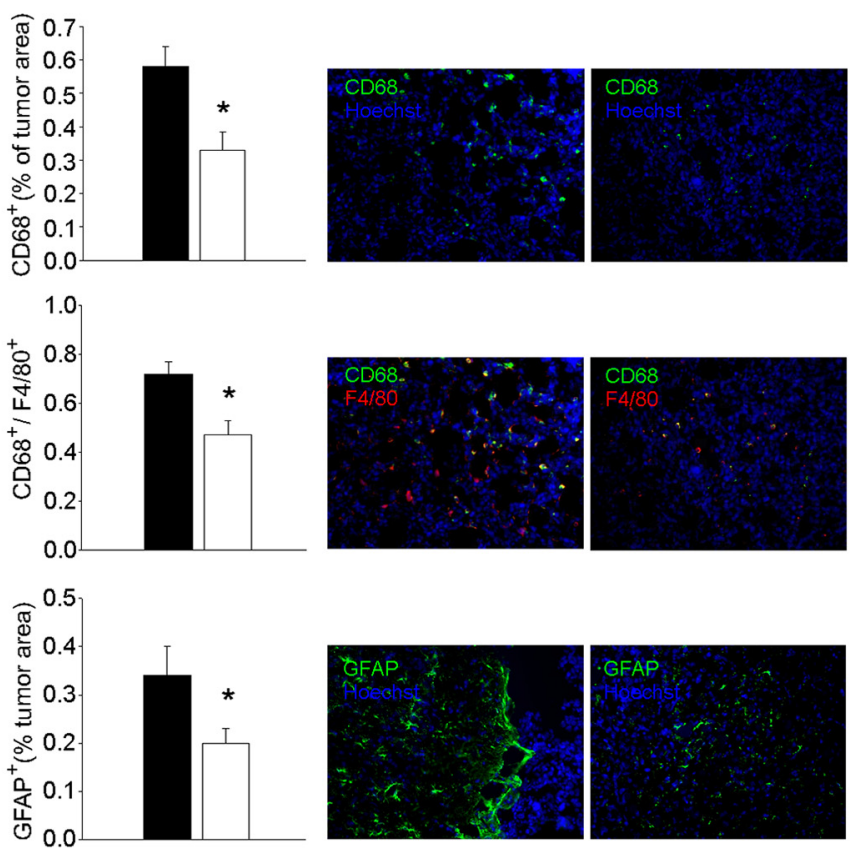

e
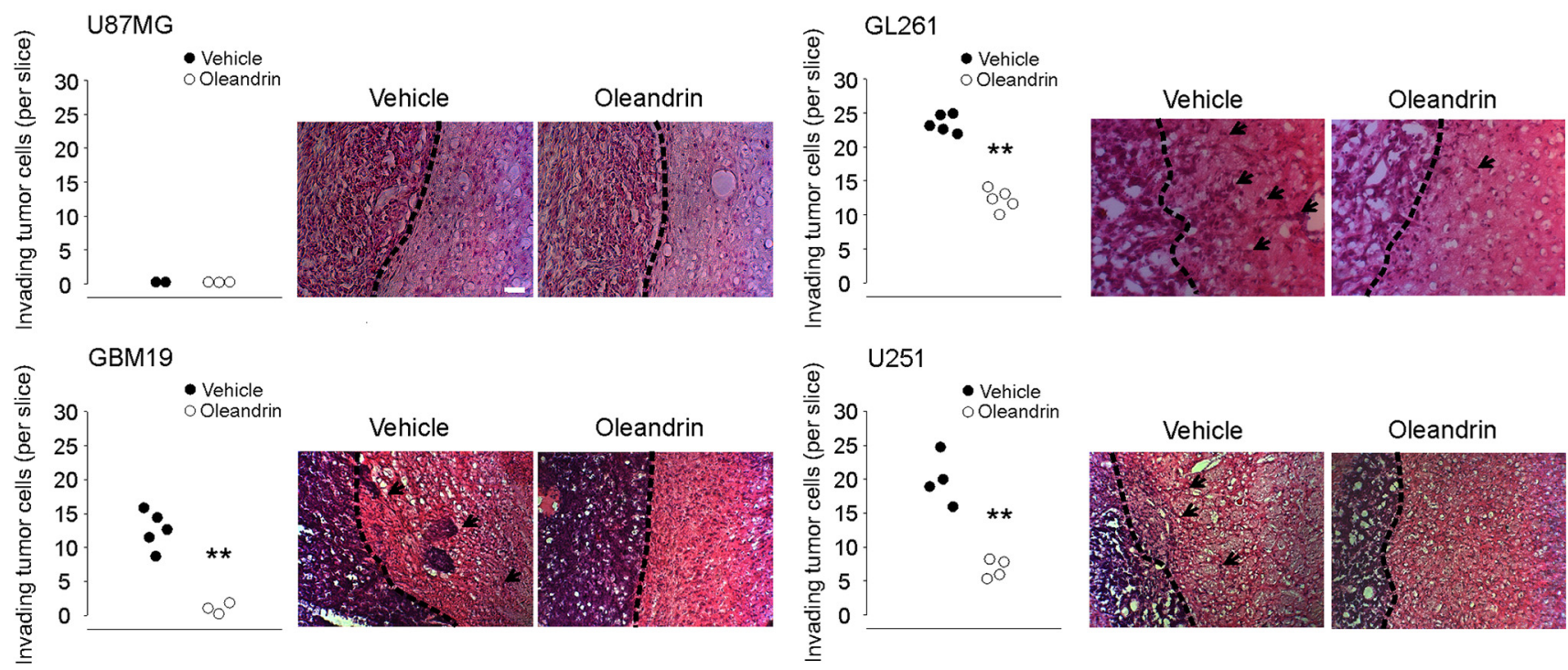

Figure 6. Effect of oleandrin in the brains of mice implanted with human or murine cells. $\boldsymbol{a}-\boldsymbol{c}$, Quantification of $\mathrm{F} 4 / 80^{+}(\boldsymbol{a}), \mathrm{CD} 68^{+}(\boldsymbol{b})$, and F4/80 ${ }^{+} / \mathrm{CD} 68^{+}(\boldsymbol{c})$ cells in the tumor area upon oleandrin or vehicle treatment. Bars represent the mean ( \pm SEM) area expressed as percentage of total tumor area. Representative immunofluorescence images are shown on the right $(n=4$ mice per condition; ${ }^{* *} p<0.01,{ }^{*} p<0.05$ Student's $t$ test). Scale bar, $100 \mu \mathrm{m}$. $d$, Quantification of GFAP ${ }^{+}$cells at the border of tumor mass (mean \pm SEM of area of as percentage of the tumor area; $n=4$ mice per condition; ${ }^{*} p<0.05$, Student's $t$ test) $17 \mathrm{~d}$ after U87MG or GL261 transplantation in mice treated with vehicle or oleandrin, as indicated. Representative immunofluorescence images are shown on the right. $\boldsymbol{e}$, Mean number ( \pm SEM) of different human and murine glioma cells invading the brain parenchyma for $>150 \mu \mathrm{m}\left(n=3-5\right.$ mice per condition; ${ }^{* *} p<0.01$, Student's $t$ test). Right, Representative coronal brain sections stained with hematoxylin and eosin. Black arrows indicate invading glioma cells beyond the main tumor border (dashed line). Scale bars, $10 \mu \mathrm{m}$ for all panels. 

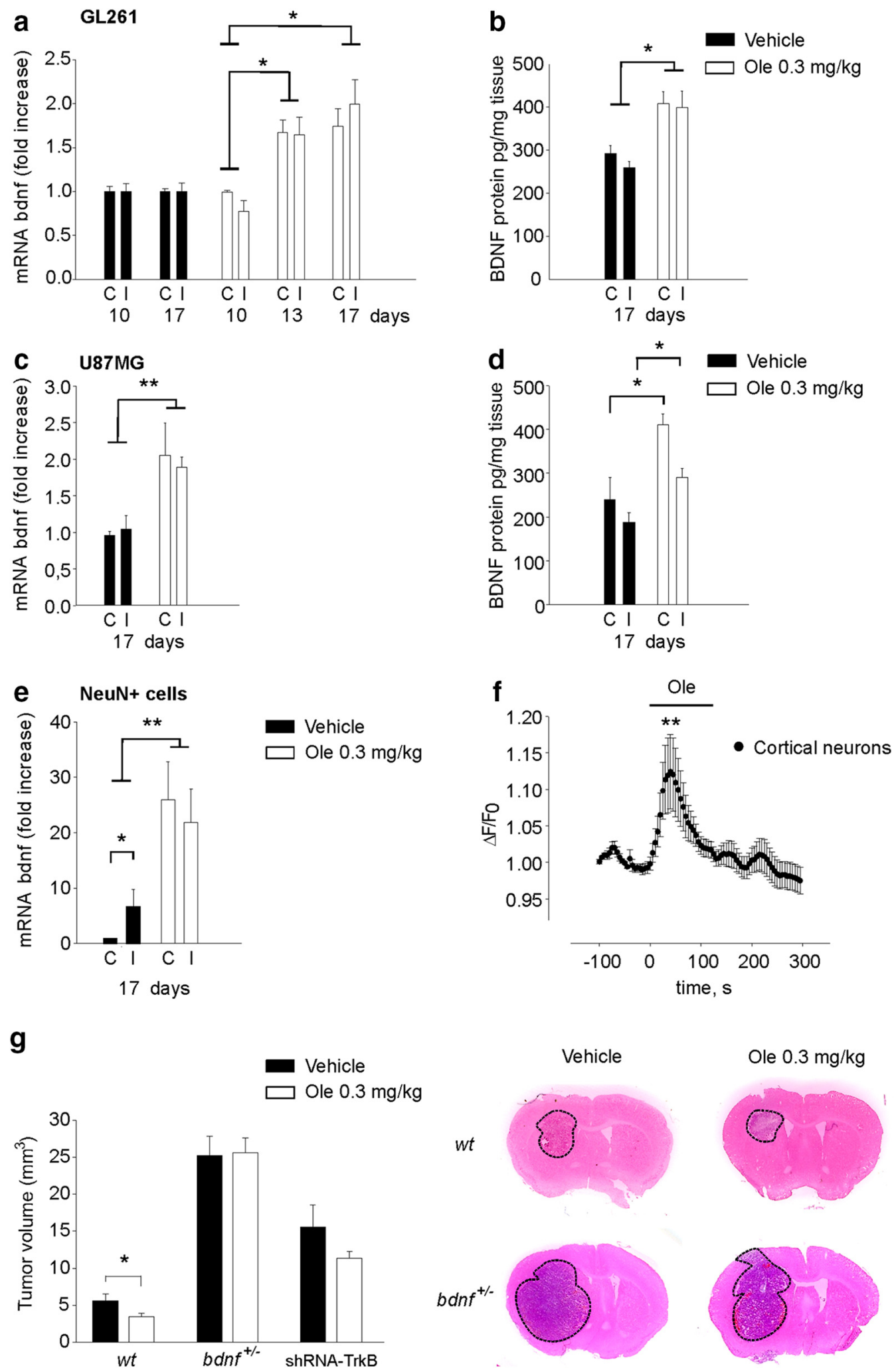

Figure 7. Oleandrin induces BDNF expression. Expression of bdnf mRNA ( $\boldsymbol{a}, \boldsymbol{c})$ and protein $(\boldsymbol{b}, \boldsymbol{d})$ in contralateral (C) and ipsilateral (I) hemispheres of GL261-bearing or U87MG-bearing mice treated with oleandrin $0.3 \mathrm{mg} / \mathrm{kg}$, as indicated. Results of RT-PCR analysis are shown as the fold increase with respect to control $\left(n=5-4 ;{ }^{*} p<0.05\right.$, ${ }^{* *} p<0.01$, one-way ANOVA followed by Dunn's posthoc test).e, Expression of $b d n f(\mathrm{mRNA})$ in NeuN ${ }^{+}$cells isolated from contralateral and ipsilateral hemispheres of GL261-bearing mice treated with vehicle or oleandrin. Results are shown as the fold increase with respect to control $\left(n=5 ;{ }^{*} p<0.05,{ }^{* *} p<0.01\right.$, one-way ANOVA followed by Tukey post hoc test). $\boldsymbol{f}$, Effect of $3 \mu \mathrm{m}$ oleandrin (the bar refers to 2 min) on Ca ${ }^{2+}$ transients in cortical neurons, expressed as $\Delta F / F 0\left(n=15,{ }^{* *} p<0.01, \chi^{2}\right.$ test). $\boldsymbol{g}$, Mean tumor volumes (GL261 and shRNA-TrkB GL261) in WT (C57BL/6) and/or bdnf ${ }^{+/-}$mice treated with oleandrin $(0.3 \mathrm{mg} / \mathrm{kg})$, as indicated $\left(n=5,{ }^{*} p<0.05\right.$, one-way ANOVA followed by Holm-Sidak post hoc test). Representative coronal brain sections are shown above for WT and $b d n f^{+/-}$mice (at $17 \mathrm{~d}$ ). 

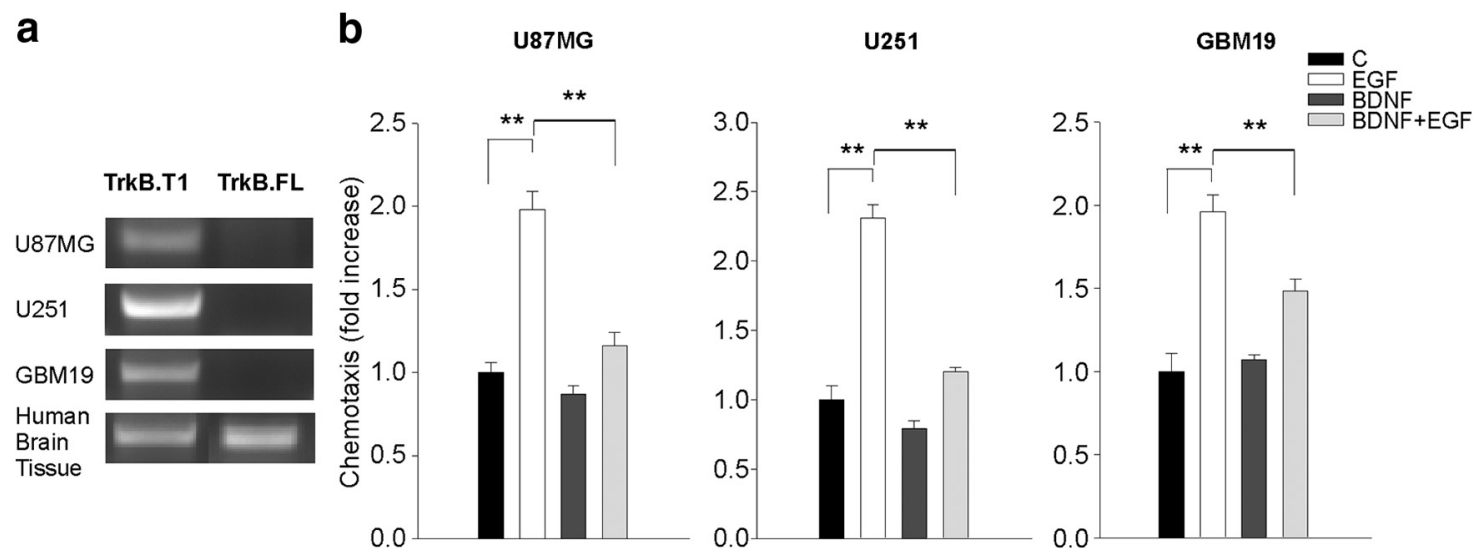

Figure 8. TrkB isoform expression and effect of BDNF on human glioma cell chemotaxis. $\boldsymbol{a}, \mathrm{RT}-\mathrm{PCR}$ analyses of TrkB isoform expression in U87MG, U251, GBM19, and normal human cerebral tissue as a control. $\boldsymbol{b}$, Glioma cell chemotaxis toward BDNF $(100 \mathrm{ng} / \mathrm{ml})$ and/or EGF (100 ng/ml). Chemotaxis is expressed as the fold increase with respect to control $\left(n=5\right.$; ${ }^{* *} p<0.01$, one-way ANOVA).

nificantly reduced by oleandrin, as indicated by the decreased GFAP staining at the tumor border $\left({ }^{*} p<0.05, n=4\right.$ mice; Fig. $6 d)$.

The effect of oleandrin on the invasion of brain parenchyma by tumor cells was investigated in cerebral slices of mice injected with human and mice glioma. In GL261-injected mice, we observed a reduced number of glioma cells protruding from the main tumor mass $\left(n=5\right.$ mice per condition; ${ }^{* *} p<0.01$; Fig. $6 e$ ), indicative of a reduced tendency of tumor cells to migrate and invade the surrounding tissue. This inhibitory effect was also observed in human U251-injected and GBM19-injected, but not in U87MG-injected mice, in which, as in the control condition, glioma cells did not invade brain parenchyma $(n=3$ mice; Fig. $6 e)$. Unlike the other cell lines used in this study, U87MG is not invasive in mouse brain parenchyma.

\section{Oleandrin enhances BDNF level in the brain}

The data reported above demonstrate that, in vivo, oleandrin can affect the growth of human and mouse glioma. However, all of our in vitro experiments indicate that oleandrin has no direct effects on murine glioma cells. To understand which mechanism could mediate the effect of oleandrin on the growth of murine glioma in vivo, we investigated brain BDNF expression and production upon oleandrin treatment (Dunn et al., 2011). We observed that oleandrin $(0.3 \mathrm{mg} / \mathrm{kg})$ increased BDNF mRNA level in the brain of GL261 glioma-bearing mice as measured $3 \mathrm{~d}$ after oleandrin administration (drug administration starting $10 \mathrm{~d}$ after glioma inoculation) and the increase was still present after $7 \mathrm{~d}$ $\left(n=5-4,{ }^{*} p<0.05\right.$; Fig. $\left.7 a\right)$. Comparable results were obtained by measuring protein BDNF levels $\left(n=5-4,{ }^{\star} p<0.05,{ }^{* *} p<\right.$ 0.01; Fig. 7b). A similar increase of BDNF mRNA and proteins was observed in the brain of SCID mice injected with U87MG cells $\left(n=5-4,{ }^{*} p<0.05,{ }^{* *} p<0.01\right.$; Fig. $\left.7 c, d\right)$.

To understand which cells produce BDNF upon oleandrin treatment, we focused our attention on neurons, the only cell type that in the brain expresses the $\alpha 3$ subunit of the $\mathrm{Na}^{+} / \mathrm{K}^{+}$ATPase (Cahoy et al., 2008). Cells from the brain of mice transplanted with GL261 were sorted for NeuN expression by FACS and analyzed for BDNF expression. The efficacy of cell sorting was verified by PCR, showing that sorted cells were positive $\beta$ TubIII and CX3CL1 and negative for CX3CR1 and GFAP (data not shown). Quantitative PCR analyses revealed that the $\mathrm{NeuN}^{+}$ cells showed increased BDNF expression upon oleandrin treatment $\left(0.3 \mathrm{mg} / \mathrm{kg} ; n=5 ;{ }^{\star} p<0.05,{ }^{*} p<0.01\right.$; Fig. $\left.7 e\right)$, thus

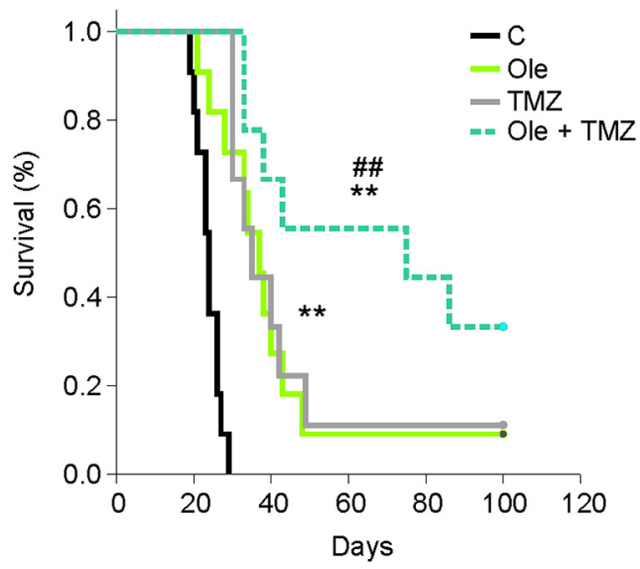

Figure 9. Oleandrin increases TMZ-induced mouse survival. Shown are Kaplan-Meier survival curves of GL261 glioma-bearing mice treated with vehicle, oleandrin (0le; $0.3 \mathrm{mg} / \mathrm{kg}$ ), TMZ $(50 \mathrm{mg} / \mathrm{kg})$, or both (0le + TMZ) $\left(n=9-11 ;{ }^{* *} p<0.01\right.$ vs control; \#\# $p<0.01$ vs TMZ and Ole, log-rank test).

revealing an effect of oleandrin on neuronal cells. To verify a direct effect of oleandrin on neurons, calcium imaging experiments were performed on cortical neurons in culture; the data reported in Figure $7 f$ show that acute oleandrin $(3 \mu \mathrm{M})$ application induced fast and reversible intracellular $\mathrm{Ca}^{2+}$ rise in $15 / 57$ neurons $\left({ }^{* *} p<0.01\right)$.

To confirm the hypothesis that BDNF could be an important mediator of oleandrin's effect on glioma, we transplanted $b d n f^{+/-}$ mice with GL261 cells and treated them with oleandrin as described above. Control experiments confirmed that oleandrin did not increase BDNF production in the brain of these mice (data not shown). At $17 \mathrm{~d}$ after glioma injection, mice were killed and brains analyzed for tumor volumes. Data shown in Figure $7 g$ indicate that $b d n f^{+/-}$mice developed larger tumors compared with their WT littermates and that, in these mice, oleandrin was ineffective in reducing tumor size $(n=5)$.

To further investigate the involvement of TrkB, we silenced TrkB by shRNA in GL261 cells, injected silenced cells in mouse brains, treated the animals with oleandrin, as described previously, and analyzed tumor volumes after $17 \mathrm{~d}$. Data reported in Figure $7 g(n=5)$ demonstrated that oleandrin is not effective in reducing tumor volumes in these mice, thus confirming that BDNF mediates the indirect effect of oleandrin on tumor cells. 


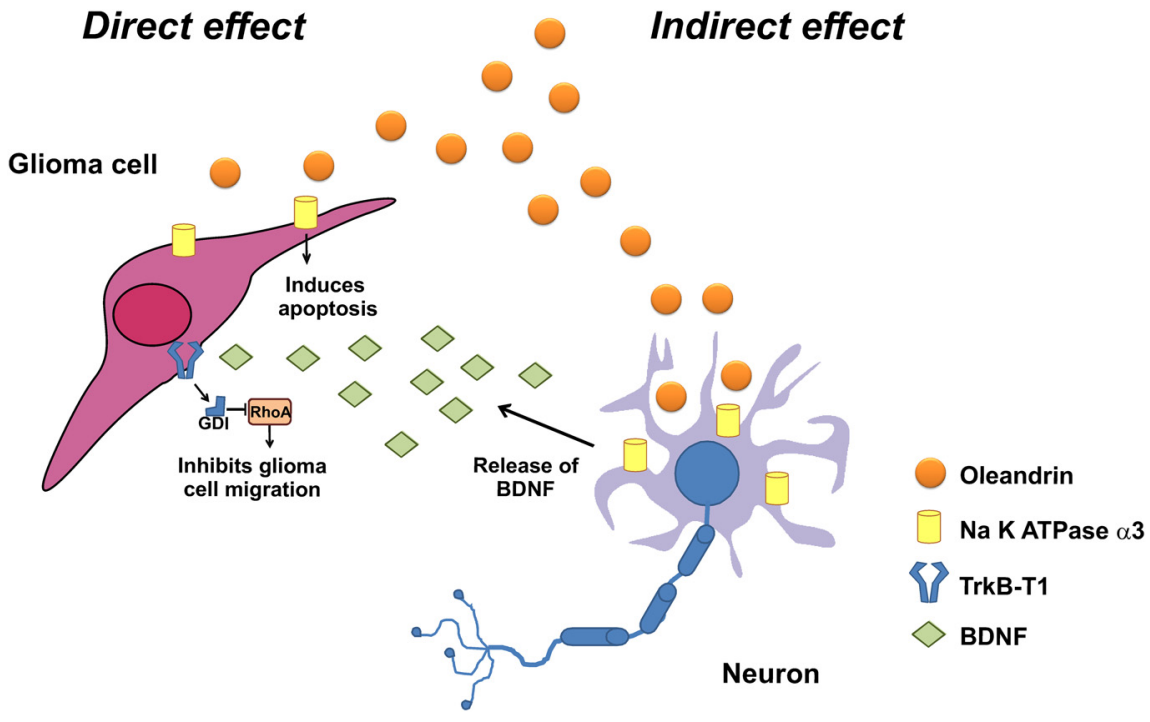

Figure 10. Schematic oleandrin effects on glioma. Oleandrin has direct effects on human GBM, reducing viability. It also stimulates neurons to release BDNF, which impairs tumor cell chemotaxis and modulates the tumor microenvironment. All of these effects contribute to reduce glioma growth in the mouse brain. See Discussion for details.

TrkB receptor expression and function were investigated using both the cell lines adopted here and in normal human brain tissue, as control. Figure 8 demonstrates that the human GBM cells used here only express the truncated TrkB.T1 and that BDNF stimulation of these cells reduced the migration induced by EGF $\left(n=5,{ }^{* *} p<0.01\right)$, confirming previous data on murine glioma (Garofalo et al., 2015).

\section{Oleandrin and TMZ cotreatment increases the survival of GL261-bearing mice}

The first-line chemotherapic drug currently used to treat glioma patients is the alkylating agent TMZ. We investigated the effect of oleandrin/TMZ cotreatment in terms of mouse survival. Mice injected with GL261 cells were treated with the drugs alone or in combination (as described in Materials and Methods). Our results (Fig. 9) demonstrated that the cotreatment (oleandrin/ TMZ) significantly prolonged mice survival with respect to single treatments (vehicle: $23.8 \pm 0.9 \mathrm{~d}, n=11$; oleandrin: $40.5 \pm 6.5 \mathrm{~d}$, $n=11$; TMZ: $43.2 \pm 7.5 \mathrm{~d}, n=9$; oleandrin + TMZ: $67.6 \pm$ $10.5 \mathrm{~d}, n=9 ;{ }^{*} p<0.01$ vs control; \#\# $p<0.01$ vs TMZ and oleandrin, log-rank test). These results highlighted the potential for therapeutic use of oleandrin in glioma in association with TMZ.

\section{Discussion}

GBM is the most frequent malignant brain tumor, with poor therapeutic perspectives for patients. Oleandrin, in the form of a Nerium oleander extract (PBI-05204), has been used as a novel drug to treat solid tumors due to its ability to kill tumor cells selectively (Manna et al., 2000). The first phase I clinical trials defined a safe dose for administration to patients of $0.2255 \mathrm{mg} / \mathrm{kg}$ (Hong et al., 2014). Oleandrin is reported to be cytotoxic to several human tumor cells such as melanoma, prostate tumor, nonsmall-cell lung cancer cells, and osteosarcoma. In these cells, it induces cell apoptosis via different mechanisms involving the activation of NF- $\kappa \mathrm{B}$ and caspase, the upregulation of death receptor 4 and 5 , and suppression of the $\mathrm{Wnt} / \beta$ catenin signaling pathway (Ma et al., 2015; Pan et al., 2015).
We have investigated for the first time the potential antitumor activity of oleandrin in glioma and found that this botanic drug reduced tumor growth in mice via direct and indirect effects on tumor cells. The direct effect of oleandrin is specific for human tumor cells and consists of apoptosis induction. The indirect effect is mediated by brain parenchyma, where oleandrin stimulated the production and release of the neurotrophin BDNF by neuronal cells. This neurotrophin has a key role in contrasting glioma growth, as demonstrated by the lack of effect of oleandrin in $b d n f^{+1-}$ mice and in mice injected with glioma cells silenced for TrkB expression by shRNA. We have also showed that oleandrin reduces microglia/macrophage infiltration and astrocyte activation and contrasts tumor cell infiltration in the healthy parenchyma.

The direct effect of oleandrin on human tumor cells relies on the higher expression of the $\alpha 3$ versus the $\alpha 1$ subunit (with respect to mouse glioma cells) of the $\mathrm{Na}^{+} / \mathrm{K}^{+}$ATPase pump and is consistent with the preferential activity of olendrin on the $\alpha 3$ subunit (Blanco, 2005). Indeed, the $\alpha 3$ subunit is highly expressed by other human tumor cells and targeting its activity with oleandrin impairs cell growth of several human tumors (Raghavendra et al., 2007). This was further confirmed in experiments in which we abolished the effect of oleandrin on cell viability by changing the $\alpha 1: \alpha 3$ ratio via overexpression of the $\alpha 1$ subunit in U87MG cells. It is important to note that oleandrin does not affect the viability of normal neurons and astrocytes and has minor effects (at high concentration only) on microglia viability. This would confirm good specificity for tumor cells also in the brains of patients with GBM; however, before considering using oleandrin in humans, it should be taken into account that, at high doses $(0.3383 \mathrm{mg} / \mathrm{kg} / \mathrm{d})$, oleandrin could induce adverse effects such as proteinuria, fatigue, nausea, diarrhea, and important cardiac alterations (Hong et al., 2014).

The efficacy of targeting the $\mathrm{Na}^{+} / \mathrm{K}^{+}$ATPase pump directly for glioma treatment is consistent with what was shown previously for another cardiac glycoside, proscillardin A, which specifically targets the $\alpha 1$ subunit on tumor cells, inducing reduced cell growth and apoptosis (Denicolai et al., 2014). Although the $\alpha 1$ subunit is expressed ubiquitously in all brain parenchymal cells (McGrail et al., 1991), investigators in that study only considered the direct effect on tumor cells. However, the ability of oleandrin to reduce tumor size and improve mice survival in animals implanted with mouse GL261 cells bearing low level of the $\alpha 3$ subunit suggests an effect of oleandrin on other cells in brain parenchyma. Consistent with this, we demonstrated that the indirect effect of oleandrin is mediated by the increased expression of the brain neurotrophin BDNF in glioma-bearing mice. An upregulation of $b d n f$ expression due to oleandrin has been already shown in vitro and correlated with the neuroprotective effect of the botanic drug PBI-05204 in an in vitro model of ischemia (Van Kanegan et al., 2014).

Here, we show for the first time that oleandrin induced $b d n f$ gene expression and protein production by neuronal cells, consistent with their specific expression of the $\alpha 3$ subunit among the brain parenchymal cells. The mechanism linking $\mathrm{Na}^{+} / \mathrm{K}^{+}$ 
ATPase activity to gene expression could involve $\mathrm{Ca}^{2+}$ transients generated by the secondary regulation of the $\mathrm{Na}^{+} / \mathrm{Ca}^{2+}$ exchanger via local alteration of the transmembrane $\mathrm{Na}^{+}$gradient, as shown for cardiomyocytes and transformed cells (Rose and Valdes, 1994; Poindexter et al., 2007). Consistently, we demonstrated that, in primary neurons in culture, oleandrin induced intracellular $\mathrm{Ca}^{2+}$ transients in a dose-dependent way. The oleandrin-induced $\mathrm{Ca}^{2+}$ transient could mediate $b d n f$ promoter activity (Lyons and West, 2011) in neurons, with BDNF production. The role of BDNF in counteracting tumor progression might be due to a direct activity on glioma cells, where it reduces their invasion ability (Garofalo et al., 2015 and the current study), but also to a protective effect on surrounding neurons, which are normally damaged by the increased levels of extracellular glutamate released by tumor cells (Mattson et al., 1995; Ye and Sontheimer, 1999). We also show that oleandrin reduced the number and modulated the activation state of tumor-infiltrating microglia/macrophage cells, an event correlated with disease severity (Hambardzumyan et al., 2016) and reduced astrocyte activation at the tumor border. These effects resemble those induced by BDNF administration in glioma-bearing mice (Garofalo et al., 2015). Accordingly, we demonstrate that BDNF plays a crucial role in the effect of oleandrin because, in $b d n f^{+/-}$mice, it failed to increase BDNF expression and was ineffective in reducing tumor volume. BDNF acts on TrkB receptors (mainly the TrkB.T1 isoform) expressed on glioma cells, as demonstrated by the inability of oleandrin to reduce tumor volume in mice transplanted with TrkB-silenced glioma cells. Our results demonstrate that oleandrin is a drug that can counteract GBM, targeting both tumor cells and the brain microenvironment. The first-line chemotherapic drug currently used to treat GBM patients is TMZ (Hirose et al., 2001); here, we showed that cotreatment of glioma bearing mice with $\mathrm{TMZ}$ and oleandrin strongly prolongs mice survival compared with TMZ treatment alone. In the light of the direct and indirect (BDNF-mediated) mechanisms induced by oleandrin on tumor cells, we speculate that this drug might also drive positive effects on GBM with the unmethylated or hypomethylated MGMT promoter. In addition, because the standard treatment for GBM patients is TMZ and adjuvant radiotherapy, it would be important to investigate in future experiments the effect of oleandrin in irradiated mice.

Altogether, these novel results describe the molecular and cellular mechanisms involved in the activity of oleandrin in tumorbearing mice, as shown in the scheme of Figure 10. These data demonstrate the increased efficacy of simultaneously targeting glioma cell proliferation, migration, and the tumor microenvironment to counteract glioma progression and pave the way for future clinical trials to test the effect of oleandrin and BDNF as coadjuvants to TMZ in humans suffering from malignant gliomas.

\section{References}

Balasubramaniam SL, Gopalakrishnapillai A, Barwe SP (2015) Ion dependence of Na-K-ATPase-mediated epithelial cell adhesion and migration. Am J Physiol Cell Physiol 309:C437-C441. CrossRef Medline

Barwe SP, Anilkumar G, Moon SY, Zheng Y, Whitelegge JP, Rajasekaran SA, Rajasekaran AK (2005) Novel role for Na, K-ATPase in phosphatidylinositol 3-kinase signaling and suppression of cell motility. Mol Biol Cell 16:1082-1094. CrossRef Medline

Biggs T, Foreman J, Sundstrom L, Regenass U, Lehembre F. J Biomol Screen (2011) Antitumor compound testing in glioblastoma organotypic brain cultures. J Biomol Screen 16:805-917. CrossRef Medline

Blanco G (2005) Na, K-ATPase subunit heterogeneity as a mechanism for tissue-specific ion regulation. Semin Nephrol 25:292-303. CrossRef Medline
Cahoy JD, Emery B, Kaushal A, Foo LC, Zamanian JL, Christopherson KS, Xing Y, Lubischer JL, Krieg PA, Krupenko SA, Thompson WJ, Barres BA (2008) A transcriptome database for astrocytes, neurons, and oligodendrocytes: a new resource for understanding brain development and function. J Neurosci 28:264-278. CrossRef Medline

Catalano M, Lauro C, Cipriani R, Chece G, Ponzetta A, Di Angelantonio S, Ragozzino D, Limatola C (2013) CX3CL1 protects neurons against excitotoxicity enhancing GLT-1 activity on astrocytes. J Neuroimmunol 263:75-82. CrossRef Medline

Cimini A, Mei S, Benedetti E, Laurenti G, Koutris I, Cinque B, Cifone MG, Galzio R, Pitari G, Di Leandro L, Giansanti F, Lombardi A, Fabbrini MS, Ippoliti R (2012) Distinct cellular responses induced by saporin and a transferrin-saporin conjugate in two different human glioblastoma cell lines. J Cell Physiol 227:939-951. CrossRef Medline

Denicolaï E, Baeza-Kallee N, Tchoghandjian A, Carré M, Colin C, Jiglaire CJ, Mercurio S, Beclin C, Figarella-Branger D (2014) Proscillaridin A is cytotoxic for glioblastoma cell lines and controls tumor xenograft growth in vivo. Oncotarget 5:10934-10948. CrossRef Medline

Dunn DE, He DN, Yang P, Johansen M, Newman RA, Lo DC (2011) In vitro and in vivo neuroprotective activity of the cardiac glycoside oleandrin from Nerium oleander in brain slice-based stroke models. J Neurochem 119:805-814. CrossRef Medline

Garofalo S, D’Alessandro G, Chece G, Brau F, Maggi L, Rosa A, Porzia A, Mainiero F, Esposito V, Lauro C, Benigni G, Bernardini G, Santoni A, Limatola C (2015) Enriched environment reduces glioma growth through immune and non-immune mechanisms in mice. Nat Commun 6:6623. CrossRef Medline

Giese A, Bjerkvig R, Berens ME, Westphal M (2003) Cost of migration: invasion of malignant glioma and implications for treatment. J Clin Oncol 21:1624-1636. CrossRef Medline

Guez-Barber D, Fanous S, Harvey BK, Zhang Y, Lehrmann E, Becker KG, Picciotto MR, Hope BT (2012) FACS purification of immunolabeled cell types from adult rat brain. J Neurosci Methods 203:10-18. CrossRef Medline

Hambardzumyan D, Gutmann DH, Kettenmann H (2016) The role of microglia and macrophages in glioma maintenance and progression. Nat Neurosci 19:20-27. CrossRef Medline

Hill SJ, Mordes DA, Cameron LA, Neuberg DS, Landini S, Eggan K, Livingston DM (2016) Two familial ALS proteins function in prevention/repair of transcription-associated DNA damage. Proc Natl Acad Sci U S A 113: E7701-E7709. CrossRef Medline

Hirose Y, Berger MS, Pieper RO (2001) p53 effects both the duration of G2/M arrest and the fate of temozolomidetreated human glioblastoma cells. Cancer Res 61:1957-1963. Medline

Hong DS, Henary H, Falchook GS, Naing A, Fu S, Moulder S, Wheler JJ, Tsimberidou A, Durand JB, Khan R, Yang P, Johansen M, Newman RA, Kurzrock R (2014) First-in-human study of pbi-05204, an oleanderderived inhibitor of akt, fgf- 2 , nf- $\kappa \mathrm{B}$ and p70s6k, in patients with advanced solid tumors. Invest New Drugs 32:1204-1212. CrossRef Medline

Jäger H, Wozniak G, Akintürk IH, Hehrlein FW, Scheiner-Bobis G (2001) Expression of sodium pump isoforms and other sodium or calcium ion transporters in the heart of hypertensive patients. Biochim Biophys Acta 1513:149-159. CrossRef Medline

Kanzawa T, Germano IM, Komata T, Ito H, Kondo Y, Kondo S (2004) Role of autophagy in temozolomide-induced cytotoxicity for malignant glioma cells. Cell Death Differ 11:448-457. CrossRef Medline

Lee SY (2016) Temozolomide resistance in glioblastoma multiforme. Genes Dis 3:198-210. CrossRef

Lenzi J, De Santis R, de Turris V, Morlando M, Laneve P, Calvo A, Caliendo V, Chiò A, Rosa A, Bozzoni I (2015) ALS mutant FUS proteins are recruited into stress granules in induced pluripotent stem cell-derived motoneurons. Dis Model Mech 8:755-766. CrossRef Medline

Li B, Hertz L, Peng L (2013) Cell-specific mRNA alterations in $\mathrm{Na}+, \mathrm{K}+$ ATPase $\mathrm{a}$ and $\mathrm{b}$ Isoforms and FXYD in mice treated chronically with carbamazepine, an anti-bipolar drug. Neurochem Res 38:834-841. CrossRef Medline

Lin Y, Dubinsky WP, Ho DH, Felix E, Newman RA (2008) Determinants of human and mouse melanoma cell sensitivities to oleandrin. J Exp Ther Oncol 7:195-205. Medline

Lyons MR, West AE (2011) Mechanisms of specificity in neuronal activityregulated gene transcription. Prog Neurobiol 94:259-295. CrossRef Medline 
Ma Y, Zhu B, Liu X, Yu H, Yong L, Liu X, Shao J, Liu Z (2015) Inhibition of oleandrin on the proliferation show and invasion of osteosarcoma cells in vitro by suppressing Wnt $/ \beta$-catenin signaling pathway. J Exp Clin Cancer Res 34:115. CrossRef Medline

Manna SK, Sah NK, Newman RA, Cisneros A, Aggarwal BB (2000) Oleandrin suppresses activation of nuclear transcription factor- $\mathrm{kB}$, activator protein-1 and c-Jun NH2-terminal kinase. Cancer Res 60:3838-3847. Medline

Mattson MP, Lovell MA, Furukawa K, Markesbery WR (1995) Neurotrophic factors attenuate glutamate-induced accumulation of peroxides, elevation of intracellular $\mathrm{Ca} 2+$ concentration, and neurotoxicity and increase antioxidant enzyme activities in hippocampal neurons. J Neurochem 65:1740-1751. Medline

McConkey DJ, Lin Y, Nutt LK, Ozel HZ, Newman RA (2000) Cardiac glycosides stimulate $\mathrm{Ca} 21$ increases and apoptosis in androgen independent, metastatic human prostate adenocarcinoma cells. Cancer Res 60:38073812. Medline

McGrail KM, Phillips JM, Sweadner KJ (1991) Immunofluorescent localization of three $\mathrm{Na}, \mathrm{K}-\mathrm{ATPase}$ isozymes in the rat central nervous system: both neurons and glia can express more than one Na, K-ATPase. J Neurosci 11:381-391. Medline

Miao H, Gale NW, Guo H, Qian J, Petty A, Kaspar J, Murphy AJ, Valenzuela DM, Yancopoulos G, Hambardzumyan D, Lathia JD, Rich JN, Lee J, Wang B (2015) EphA2 promotes infiltrative invasion of glioma stem cells in vivo through cross-talk with Akt and regulates stem cell properties. Oncogene 34:558-567. CrossRef Medline

Nasu S, Milas L, Kawabe S, Raju U, Newman R (2002) Enhancement of radiotherapy by oleandrin is a caspase- 3 dependent process. Cancer Lett 185:145-151. CrossRef Medline

Ni D, Madden TL, Johansen M, Felix E, Ho DH, Newman RA (2002) Murine pharmacokinetics and metabolism of oleandrin, a cytotoxic component of Nerium oleander. J Exp Ther Oncol 2:278-285. CrossRef Medline

Pan Y, Rhea P, Tan L, Cartwright C, Lee HJ, Ravoori MK, Addington C, Gagea M, Kundra V, Kim SJ, Newman RA, Yang P (2015) PBI-05204, a supercritical $\mathrm{CO}_{2}$ extract of Nerium oleander, inhibits growth of human pancreatic cancer via targeting the PI3K/mTOR pathway. Invest New Drugs 33:271-279. CrossRef Medline

Pinheiro R, Braga C, Santos G, Bronze MR, Perry MJ, Moreira R, Brites D, Falcão AS (2017) Targeting gliomas: can a new alkylating hybrid compound make a difference? ACS Chem Neurosci 8:50-59. CrossRef Medline

Poindexter BJ, Feng W, Dasgupta A, Bick RJ (2007) Oleandrin produces changes in intracellular calcium levels in isolated cardiomyocytes: a realtime fluorescence imaging study comparing adult to neonatal cardiomyocytes. J Toxicol Environ Health A 70:568-574. CrossRef Medline
Preusser M, de Ribaupierre S, Wöhrer A, Erridge SC, Hegi M, Weller M, Stupp R (2011) Current concepts and management of glioblastoma. Ann Neurol 70:9-21. CrossRef Medline

Raghavendra PB, Sreenivasan Y, Manna SK (2007) Oleandrin induces apoptosis in human, but not in murine cells: dephosphorylation of Akt, expression of FasL, and alteration of membrane fluidity. Mol Immunol 44:2292-2302. Medline

Rajasekaran SA, Barwe SP, Rajasekaran AK (2005) Multiple functions of Na, K-ATPase in epithelial cells. Semin Nephrol 25:328-334. CrossRef Medline

Rose AM, Valdes R Jr (1994) Understanding the sodium pump and its relevance to disease. Clin Chem 40:1674-1685. Medline

Rosskopf D, Düsing R, Siffert W (1993) Membrane sodium-proton exchange and primary hypertension. Hypertension 21:607-617. CrossRef Medline

Schmittgen TD, Livak KJ (2008) Analyzing real-time PCR data by the comparative $\mathrm{C}(\mathrm{T})$ method. Nat Protoc 3:1101-1108. CrossRef Medline

Sciaccaluga M, Fioretti B, Catacuzzeno L, Pagani F, Bertollini C, Rosito M, Catalano M, D'Alessandro G, Santoro A, Cantore G, Ragozzino D, Castigli E, Franciolini F, Limatola C (2010) CXCL12 induced glioblastoma cell migration requires intermediate conductance $\mathrm{Ca}^{2+}$-activated $\mathrm{K}^{+}$ channel activity. Am J Physiol Cell Physiol 299:C175-C184. CrossRef Medline

Stupp R, Hegi ME, Mason WP, et al. (2009) Effects of radiotherapy with concomitant and adjuvant temozolomide versus radiotherapy alone on survival in glioblastoma in a randomised phase III study: 5-year analysis of the EORTCNCIC trial. Lancet Oncol 10:459-466. CrossRef Medline

Tajima N, Itokazu Y, Korpi ER, Somerharju P, Käkelä R (2011) Activity of $\mathrm{BK}(\mathrm{Ca})$ channel is modulated by membrane cholesterol content and association with $\mathrm{Na}+/ \mathrm{K}+$-ATPase in human melanoma IGR39 cells. J Biol Chem 286:5624-5638. CrossRef Medline

Van Kanegan MJ, He DN, Dunn DE, Yang P, Newman RA, West AE, Lo DC (2014) BDNF mediates neuroprotection against oxygen-glucose deprivation by the cardiac glycoside oleandrin. J Neurosci 34:963-968. CrossRef Medline

Volonte C, Ciotti MT, Merlo D (1994) LiCl promotes survival of GABAergic neurons from cerebellum and cerebral cortex. Neurosci Lett 172:6-10. Medline

Yang P, Menter DG, Cartwright C, Chan D, Dixon S, Suraokar M, Mendoza G, Llansa N, Newman RA (2009) Oleandrin-mediated inhibition of human tumor cell proliferation: Importance of $\mathrm{Na}$, K-ATPase a subunits as drug targets. Mol Cancer Ther 8:2319-2328. CrossRef Medline

Ye ZC, Sontheimer H (1999) Glioma cells release excitotoxic concentrations of glutamate. Cancer Res 59:4383-4391. Medline 